\title{
Nens que escriuen i nens que parlen: una altra visió medieval de Crist Jutge
}

\author{
Guadaira Macías Prieto \\ Universitat de Barcelona. Departament d'Història de l'Art \\ guadairamacias@ub.edu
}

Recepció: 05/03/2020, Acceptació: 21/09/2020, Publicació: 28/12/2020

\begin{abstract}
RESUM
En aquest article estudiarem, a través de diverses obres catalanes, algunes variants de la iconografia de la Mare de Déu amb el Nen que escriu. Revisarem com aquest motiu, notablement polisèmic $i$ de gran èxit en el corrent artístic denominat "gòtic internacional», es concreta en tres exemples: en l'única miniatura coneguda del Levador del plat de pobres vergonyants, un còdex desaparegut que va pertànyer a l'església de Santa Maria del Mar, de Barcelona; en la Mare de Déu amb el Nen, les virtuts cardinals i altres figures, que fou probablement la taula cimera del Retaule de sant Jordi de la Generalitat, pintat per Bernat Martorell; i en el compartiment principal del Retaule de la Mare de Déu i sant Vicenç Ferrer, de Pere Garcia de Benavarri. Els ingredients escatològics i d'altres tipus, fornits pels contextos on s'insereixen aquestes representacions, legitimen, com veurem, la interpretació d'aquests «nens» que escriuen, que llegeixen o que parlen com una opció de representació medieval de Crist Jutge. En aquest cas, però, sota una fórmula que renuncia als accents més majestuosos i cruents del Judici per adoptar una forma amable i fins i tot tendra, que afavoreix, a més, la comunicació amb el donant, individual o col-lectiu. Els exemples catalans estudiats, d'altra banda, permeten establir vincles compositius i significatius amb destacades obres europees $\mathrm{i}$ apropar-nos, així, a la circulació de motius i models entre els anys I 390 i i 460, aproximadament.
\end{abstract}

Paraules clau:

pintura; llibres il-luminats; retaule; gòtic; Catalunya; iconografia; Crist; Mare de Déu; jutge; escriptura

\section{Children who write and children who speak: Another medieval vision of Christ the Judge}

In this article we will study, through various Catalan works, some variants of the iconographic motif of the Madonna of the Writing Christ Child. We will review how this motif, remarkably polysemic and which is so successful in the artistic style known as "Gothic International", is illustrated in three examples: a miniature from the Levador del plat de pobres vergonyants, a lost codex from the church of Santa Maria del Mar in Barcelona; on the panel with the Virgin with the Child, the cardinal virtues and other figures, probably the topmost central section of the Altarpiece of Saint George of the Generalitat, by Bernat Martorell; and in the main compartment of the Altarpiece of the Virgin and Sant Vicenç Ferrer by Pere Garcia de Benavarri. The eschatological ingredients and other aspects, provided by the contexts in which these representations are inserted, legitimize, as we shall see, the interpretation of these "children" who write, read or speak as an option for the medieval representation of Christ the Judge, in this case, however, employing a formula that renounces the most majestic and bloodiest accents of the Judgment to adopt a kind and even tender form, which also favors communication with the donor, individually or collectively. The Catalan examples studied here also allow us to establish significant compositional links with outstanding European works and thus to approach the circulation of motifs and models between approximately 1390 and 1460 .

Keywords:

painting; illuminated manuscript; altarpiece; Gothic; Catalonia; iconography; Christ; Virgin; Judge; writing 
$\mathrm{L}$ a Mare de Déu amb l'Infant als braços és un dels temes estrella de l'imaginari gòtic. la seva forma escultòrica, des del mainell o timpà de les esglésies, vigila i protegeix l'accés als temples, triomfant de vegades sobre feres que al-ludeixen a les potències malignes. Tallada en pedra, marbre o alabastre, però també en fusta o feta de metalls preciosos, la Verge amb el Nen ocupa habitualment l'altar i esdevé icona i objecte de devoció. Presideix també, en fi, innombrables retaules - pintats, esculpits o mixtos - aglutinant advocacions particulars i programes iconogràfics diversos. Com la historiografia ha posat en relleu, el desenvolupament del culte marià i la devoció popular envers la seva figura, d'una banda, així com el creixent naturalisme que impregna les arts al llarg de la baixa edat mitjana, de l'altra, contribueixen en gran mesura a explicar la ubiqüitat de la imatge de la Mare de Déu amb el Nen, i també la variabilitat de la seva formulació concreta ${ }^{1}$. Destaquen, en moltes d'aquestes obres d'art, l'elegància de la figura femenina i la tendresa de l'Infant, així com l'especial connexió afectiva que s'estableix entre tots dos. $\mathrm{Al}$ marge, però, d'aquests aspectes, que apel-len encara a la nostra sensibilitat, igual com ho devien fer amb el públic de l'edat mitjana, la parella constituida per Maria i Jesús s'acoloreix amb l'addició d'atributs específics i, en ocasions, d'una gestualitat concreta que, més enllà de l'encant artístic i de l'efecte emocional, incorporen complexes referències simbòliques que requereixen, en molts casos, una lectura atenta $\mathrm{i}$ un coneixement aprofundit no només dels llibres de la Bíblia, la producció dels teòlegs o els escrits dels místics i les místiques de l’edat mitjana, sinó també d'algunes pràctiques devocionals i paralitúrgiques i, fins i tot, folklòriques.
Al llarg d'aquest estudi ens centrarem en l'anàlisi d'uns atributs que doten d'un caràcter particular la figura del Nen Jesús, acompanyat sempre de la seva mare. La fórmula iconogràfica a la qual pararem atenció és la que representa Jesús com un nadó o un petit infant llegint o escrivint en braços de Maria, ocupat, doncs, en una tasca intel-lectual del tot impròpia de la seva curta edat. El desenvolupament del culte al Nen, que es concreta en fórmules artístiques específiques, $s$ 'ha associat en alguns casos a un desenvolupament previ o paral-lel de la místi$\mathrm{ca}$, l'espiritualitat $\mathrm{i}$ les pràctiques litúrgiques $\mathrm{i}$ paralitúrgiques femenines, tant en els centres monàstics $i$ conventuals com en altres contextos $^{2}$. S'ha suposat, i de vegades és veritat, que certes pràctiques, creences i imatges vinculades a l'embaràs de Maria, l'infantament, la criança i l'educació del Nen responien a la sublimació d'experiències vitals a les quals les monges renunciaven en professar els seus vots. No hem d'oblidar, però, que místics i teòlegs de gènere masculí es van interessar també per aquests aspectes i que a finals de l'edat mitjana es produí fins i tot, segons com, una «maternalització» de la figura de Crist que va ser teoritzada per homes, alguns d'ells adscrits a contextos monàstics com ara el cistercenc ${ }^{3}$. No podem oblidar, a més, que aquestes imatges de Maria amb el Nen, que posen l'accent en detalls aparentment mundans i naturals i que permeten incloure tota una panòplia d'elements quotidians, luxosos, sofisticats o anecdòtics, encaixen a la perfecció amb el gust i les constants estilístiques del gòtic internacional. Els motius iconogràfics que volem analitzar en aquest estudi es detecten a les darreres dècades del segle XIV i cap a l'any I 400, el moment en què cristal-litza aquest estil caracteritzat, en primer lloc, per la seva difusió relativament homogènia 
arreu d'Europa, malgrat algunes particularitats «regionals» que la historiografia ha posat de relleu en les darreres dècades. I, en segon lloc, per un marcat gust pels contrastos: el gòtic internacional conjuga la sofisticació formal i significativa amb l'anècdota més vulgar, la idealització cortesana amb el naturalisme. Aquesta dualitat reflecteix també una dicotomia en el seu origen, que hem de situar en la confluència entre les aportacions a la construcció de l'espai i la figura del Trecento centreitalià i l'elegància cal-ligràfica de la cultura parisenca i, en general, del nord de França i els Països Baixos ${ }^{4}$.

No són els artistes gòtics els que posen per primera vegada el llibre o el filacteri en mans del Nen. El còdex és un atribut habitual de les majestats romàniques $i$ apareix també, obert $o$ tancat, amb escriptura o sense, en mans del Jesús que seu sobre els genolls de la Verge, en imatges pintades o esculpides. No resulta estrany que s'esculli aquest atribut en el context de la fórmula de Maria com a Sedes Sapientiae: si Jesús és el Logos, l'encarnació de la saviesa, quin millor?5. En època gòtica, com ja sabem, la representació de Maria amb el Nen varia i el llibre pren també un caràcter diferent. D'una banda, ja no és gaire habitual: guanyen presència uns altres elements com ara les flors $i$ les fruites o els ocells, entre els quals destaca la cadernera. Uns i altres permeten, per descomptat, que se'n realitzi una lectura en clau simbòlica, però són, a la vegada, elements que afavoreixen la interacció entre mare i fill i que faciliten una actitud juganera i natural del Nen. Quan s'opta pel llibre o pel filacteri, en aquest nou context gòtic, Jesús no només l'ostenta, sinó que també es presenta actiu en referència a aquests objectes: escriu, llegeix, n'assenyala algun passatge a la seva mare $\mathrm{o}$ a uns altres personatges, en rebrega les pàgines... Hi concorren, a més, en alguns casos, uns altres factors que ens permeten dibuixar escenaris significatius més precisos.

La imatge de Jesús llegint o escrivint en braços de la seva mare encaixa còmodament en un ambient baixmedieval, on la cultura librària pren cada cop més importància ${ }^{6}$, i podríem pensar que també, com a escena narrativa, en la representació cada cop més extensa i detallada que es fa de la infància de Crist. Aquest desenvolupament narratiu afecta d'igual manera la illustració de la vida de Maria, i és cert que a ella la veiem, en l'àmbit dels manuscrits il.luminats i els retaules, però també en escultures i relleus, aprenent a filar, teixir o llegir, de vegades acompanyada de la seva pròpia mare, santa Anna. Serà ara, justament, quan prengui cos la fórmula de «santa Anna triple» o l'anomenada, amb poca correcció teològica, «Trinitat femenina», que conjuga les figures de santa Anna, Maria i el Nen, amb la voluntat, entre d'altres, d'insistir en la concepció miraculosa de la Verge. Molt sovint el llibre és l'atribut que acompanya les tres figures, habitualment en mans de Maria o d'Anna. Una xilografia de cap a I450-I460, probablement obra d'un autor suabi, presenta una iconografia poc freqüent connectada amb el tema que ens ocupa: una santa Anna monumental acull a la seva falda Maria, que sosté un llibre on escriu Jesús ${ }^{7}$. Una altra fórmula iconogràfica on concorren dones, nens i llibres a finals de l'edat mitjana és la de la «santa parentela», és a dir, la representació de la Verge acompanyada de santa Anna i les seves altres filles, amb els seus fills respectius (els misteriosos «germans» de Jesús mencionats en alguns dels evangelis canònics) i, de vegades, els esposos d'Anna o les seves filles, habitualment situats en un lloc secundari ${ }^{8}$. Al meu parer, però, tot $\mathrm{i}$ que en aquestes imatges algunes de les dones sostenen llibres a les mans o sobre la falda, no sembla, en general, que es dediquin a ensenyar lletres a la seva prole. L'atribut funciona més aviat com a vehicle per meditar sobre els misteris sagrats. Així succeeix en un dels exemples més antics d'aquesta iconografia, la taula central del retaule d'Ortenberg, al Landesmuseum de Darmstadt, de cap a I 4 IO (inv. núm. GK 4), o al retaule centrat per aquest tema probablement provinent de l'hospital de Sant Heribert de Colònia, ara al Wallraf-Richartz Museum de la ciutat, de cap a I420. D'altra banda, la Verge es vincula a la paraula escrita i a la cultura librària en contextos diversos al del seu procés d'aprenentatge en la infantesa. Voldria cridar l'atenció, sense entrar ara en una anàlisi a fons, sobre la forma particular que pren l'Anunciació en dos retaules adscrits al catàleg del pintor lleidatà Jaume Ferrer. Als compartiments dedicats a aquest tema als conjunts provinents de l'església parroquial de Santa Maria de Verdú (Museu Episcopal de Vic, inv. 1773) i de la Paeria de Lleida (encara sencer $\mathrm{i}$ in situ), Maria se situa davant d'un escriptori ocupat pels nombrosos estris propis de la tasca de l'escrivà i destinat, doncs, a l'activitat intellectual i no només la pregària. Resulta especialment interessant el cas de Verdú, on el llibre obert sobre l'escriptori està pautat, però encara no inclou text. Es tracta, potser, d'una al-lusió simbòlica al nou relat evangèlic que està a punt de concretar-se en l'Encarnació de Crist, però, en tot cas, es transmet amb una imatge de caire naturalista que presenta la dona com a escriptora, a més de com a lectora?.

L'àmbit domèstic que contextualitza les anunciacions citades és, tot $i$ algunes excepcions, absent en la majoria d'imatges del Nen Jesús escrivint (o llegint) que hem conservat, $i$ això en dificulta la inclusió i la interpretació 
com a part del seu relat biogràfic ${ }^{10}$. Malgrat que altres escenes basades en fonts apòcrifes van tenir un cert predicament artístic, no sembla que l'educació de Jesús hi acabés de trobar el seu espai. La idea de la divinitat aprenent i, doncs, perfeccionant-se, devia trasbalsar els teòlegs, tot i que va ser parcialment acceptada per alguns. És el cas, per exemple, de Tomàs d'Aquino, qui va proposar que, si bé Crist és l'encarnació de la saviesa, al llarg de la seva experiència vital, i gràcies a aquesta, progressà en cognitio experimentalis $^{11}$. A partir d'aquest i d'altres plantejaments teòrics, Mary McDevitt defensa l'existència de la iconografia de Jesús aprenent a escriure i creu que aquest tipus iconogràfic concret de la Mare de Déu amb el Nen podia haver estat el punt de partida d'algunes representacions baixmedievals de la gramàtica. En alguns casos, aquest art liberal s'il-lustra mitjançant una figura femenina i maternal que acull el seu deixeble i, fins i tot, l'alleta. Això no obstant, no hem d'oblidar que una formulació plàstica similar, o fins i tot derivada d'una altra, no sempre implica un transvasament de significat. El fet és que, segons la meva opinió, algunes imatges que s'han interpretat en clau d'aprenentatge poden tenir, més aviat, un significat escatològic, relatiu al Judici Final i la Redempció, igual com passa amb les peces catalanes que analitzarem més detalladament en aquest estudi. McDevitt interpreta Maria com a mestra de Jesús, per exemple, en una miniatura que il-lustra l'inici de les lletanies de la Verge en un còdex de finals del segle xv conservat a la British Library de Londres ${ }^{12}$ (figura I). La imatge, però, és lluny de tenir lloc en un espai domèstic relatiu a la infància de Crist, tot i que òbviament es fa referència a aquesta infància $i$ a la relació privilegiada de Maria amb el Salvador, aspecte clau en la seva consideració com a intercessora del gènere humà. La Verge seu en una cadira de tisora, sota un drap d'honor sostingut per àngels a manera de baldaquí, davant d'un paisatge amb una ciutat al fons. La flanquegen dues altres figures angèliques amb encensers $i$ el setial se situa en un espai arquitectònic que hostatja, a més, quatre àngels amb trompetes. Tant la construcció espacial com aquests àngels trompeters $\mathrm{i}$ turiferaris remeten a un àmbit escatològic i a una situació on Maria no ensenya sinó que potser més aviat actua com a mitjancera pel bon destí d'aquells que el seu fill li va assenyalant en un llibre que podria al-ludir al Llibre de la Vida. Les paraules «Sancta Maria. Ora pro» que acompanyen la imatge redunden en aquest sentit. Em sembla que també pot tenir aquesta interpretació la interessant Mare de Déu de les Febres atribuïda a Bernardino di Benedetto di Biagio, dit Il Pinturicchio (Perugia, ca. I454 Siena, I 513), procedent de la col-legiata de Xà- tiva i ara conservada al Museu de Belles Arts de València (inv. 273). Manuel Trens citava aquesta peça com a exemple de "pintoresquismo" perillós justament en interpretar-la com Crist aprenent a llegir i escriure ${ }^{13}$. La presència del donant agenollat, això no obstant, i el gest del Nen, que assenyala un passatge concret del llibre, així com l'actitud de Maria, més aviat fan pensar en un context de nou escatològic ${ }^{14}$.

D'altra banda, relats com ara el del Nen perdut i retrobat al Temple, que presenten un Jesús de curta edat entre llibres, capaç d'avergonyir els savis $i$ «renyar» els seus pares al-ludint a esdeveniments futurs, són molt més habituals en la plàstica gòtica. La representació d'aquesta escena es fa un lloc a la retaulística catalana i aragonesa, per exemple, en contextos gogístics, com al Retaule de la Mare de Déu de Sixena, sorgit del taller barceloní dels Serra, o en conjunts dedicats «al Salvador», com al retaule d'aquesta advocació d'Ejea de los Caballeros ${ }^{15}$. Aquest infant que des de ben petit posseeix una sapiència completa em sembla clau per interpretar unes altres imatges de Jesús amb el llibre que estan mancades d'un context narratiu precís.

El tema que ara atreu el nostre interès ha estat estudiat en diversos articles que han parat una atenció especial a la seva concreció primerenca en els formats escultòrics i pictòrics, intentant establir tipologies genèriques, així com el lloc $\mathrm{i}$ el moment d'aparició $\mathrm{i}$ la seva dispersió geogràfica posterior, sense exhaurir, però, en absolut, les interpretacions del tipus, que presenta una notable variabilitat en combinar-se amb altres models iconogràifics, amb atributs diversos i en envoltar-se de contextos específics. Cal destacar molt especialment les aportacions de Charles P. Parkhurst Jr. en un article pioner de I94I on realitza una àmplia aproximació al motiu i assaja una primera distribució cronològica, geogràfica i tipològica ${ }^{16}$. Parkhurst situa el naixement del tema a finals del segle xiv al nord d'Europa, just en el moment en què aquesta zona comença $a$ adquirir un relleu cultural molt important. L'autor divideix els trenta-vuit exemplars que llista en dos tipus: la Mare de Déu amb l'Infant dempeus, que considera sorgida dins del camp escultòric, malgrat que més tard se'n trobin exemples pintats i gravats, i la Mare de Déu entronitza$\mathrm{da}$, que, segons el seu parer, va néixer en la illustració de manuscrits, tot i que també migrés al camp escultòric en una segona etapa. Afirma, a més, que totes dues tipologies es poden subdividir segons la gestualitat precisa de Jesús: en alguns casos el Nen escriu, però en d'altres aquesta activitat és només suggerida per la presència del còdex o filacteri i el tinter. Cal tenir en compte també que, com indica l'estudiós, en algunes imatges de la Verge dempeus el Nen estira 
el mantell de la seva mare, en un gest que sembla al-ludir a la Mare de Déu de la Llet. Algunes de les verges sedents, d'altra banda, es representen efectivament alletant el Nen. Parkhurst no ressenya cap exemple medieval en terres hispàniques $i$ considera que «The final stage in the International dissemination of the image is its entry into Spanish painting» ja en un context de penetració de les formes renaixentistes, tot citant dues obres atribuïdes a Luis de Morales ${ }^{17}$. Aquesta primera i comprensiva anàlisi de Parkhurst ha estat seguida més tard per estudis parcials, principalment a partir d'exemples concrets. En destaca la publicació de William Wixon amb motiu de l'adquisició, per part del Cleveland Museum of Art, d'una excel-lent escultura de la Mare de Déu amb el Nen escrivint (John L. Severance Fund I970.13). L'autor estableix la connexió estilística $\mathrm{i}$ iconogràfica amb exemples miniats i escultòrics de l'entorn de les corts franceses de cap al I 400, i especialment amb el cercle artístic del duc de Berry. Fa també algunes breus consideracions sobre la iconografia de la peça, tot i que no l'analitza en profunditat més enllà de la filiación ${ }^{18}$. W. H. Forsyth estudia un altre exemplar vinculat a les corts borgonyones: la monumental Mare de Déu amb el Nen del Metropolitan Museum atribuïda a Claus de Werve i procedent del convent de clarisses de Poligny, fundat per la influent reformadora Colette de Corbie, que a més va estar sota el patrocini de Joan Sense Por i Margarida de Baviera ${ }^{19}$. Aquest exemplar convida a reflexionar sobre «l'ús» d'aquest tipus d'imatge: l'autor afirma que devia ocupar un espai de la clausura restringit a les monges, on hauria presidit, segons sembla que es desprèn d'alguns documents, les reunions de la comunitat. Aquesta peça inclou també la peculiaritat d'estar acompanyada d'una inscripció al costat del setial de Maria on es pot llegir: «Ab · ini / tio · et / ante / secula / creata . / sum $»^{20}$. Es tracta d'un passatge de l'Eclesiàstic $(24,9)$ referit a la «Saviesa» que podria al-ludir a Crist, el Logos o el Verb encarnat, però que en alguns casos s'ha interpretat com una metàfora de la creació sense màcula i abans del temps de la Verge i s'ha vinculat amb la representació de la Mare de Déu amb atributs apocalíptics ${ }^{21}$, la qual cosa no deixa de ser interessant si pensem que algunes de les Verges amb l'Infant escrivint o llegint inclouen aquests elements. És el cas d'un esplèndid tondo amb la Mare de Déu asseguda sobre el creixent de lluna amb el Nen escrivint, conservat a The Walters Art Museum (inv. 37.2404), que estudia Philippe Verdier ${ }^{22}$ (figura 2). El tondo és, com remarca aquest autor, una obra peculiar. Per les dimensions reduïdes $i$ el seu format circular sembla una peça adequada per a un context privat, un oratori o una cambra particular. D'altra banda, aquest mateix format

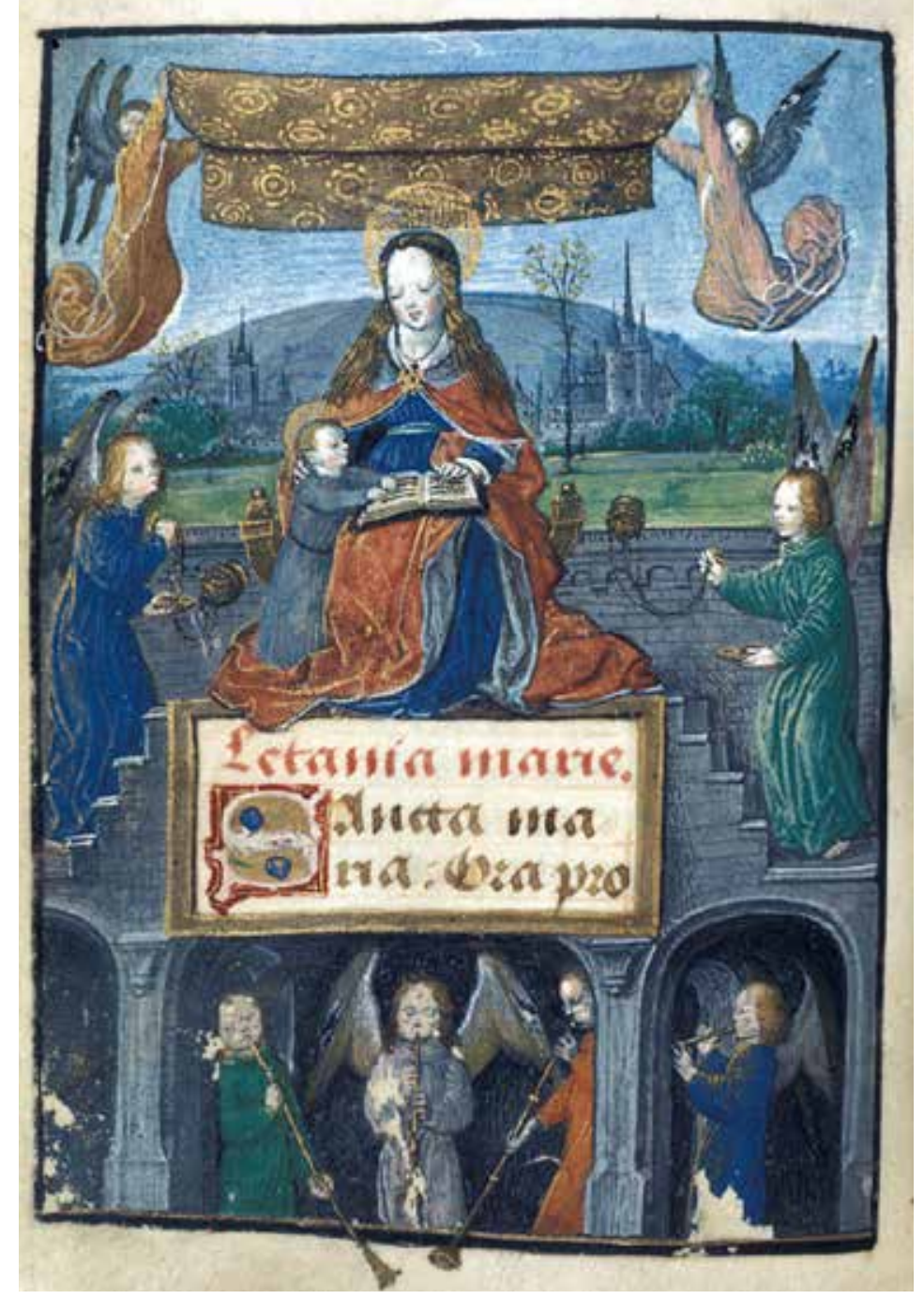

Figura 1.

Mestre del Llibre de pregàries de Dresde, Mare de Déu amb el Nen que escriu, miniatura d'un llibre d'hores. Londres, British Library, ms. Egerton 2045, f. 216v.

la connecta amb luxosos miralls, historiats preferentment amb la imatge de la Mare de Déu amb el Nen, consignats als inventaris dels bens d'alguns personatges molt destacats de les corts franceses $\mathrm{i}$ borgonyones de cap al I 400 . Més recentment, Joaneath Spicer ha estudiat aquesta obra sota el suggestiu títol de La Vierge à l'Enfant qui écrit ou le Miroir de la Vertu ${ }^{23}$. Entre les darreres aportacions a l'estudi del tema iconogràfic que ens ocupa en destaca la d'Agnieszka LagunaChevillotte, qui se centra en el camp escultòric $i$ en el context cortesà o reial francès del voltant de $1400^{24}$. L'autora subratlla la variabilitat de les tipologies, els suports i els estris d'escriptura que poden portar el Nen i la Mare, com també la diversa gestualitat que mostren les escultures. Laguna-Chevillotte sembla veure en la majoria d'aquests grups, on la Mare de Déu i l'Infant centren l'atenció sobre un llibre o un filacteri (escrivint o no), una il-lustració simbòlica de 


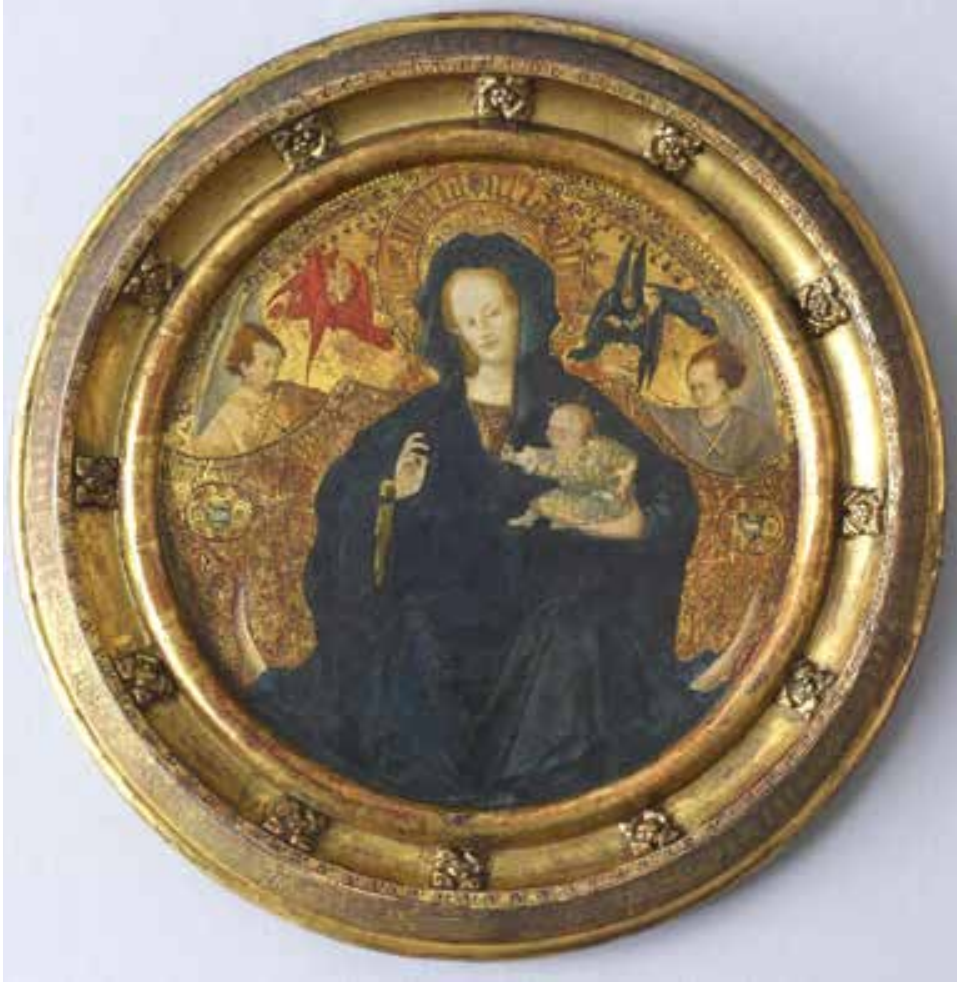

Figura 2

Cercle de Conrad von Soest (?), La Mare de Déu amb el Nen que escriu i àngels. Baltimore, The Walters Art Museum (inv. 37.2404).

l'Antiga i la Nova Llei, de la substitució de l'antiga aliança entre Déu i els homes per una de nova. Considera un dels primers exemples d'aquesta iconografia la Mare de Déu amb el Nen de l'església de Saint-Just d'Arbois, que data cap a $1375-1378$, i afirma que es tracta «du sujet de l'Enfant-Sauveur écrivant les paroles de la nouvelle loi, sous le regard attentif de la ViergeÉglise» ${ }^{25}$. Aquesta interpretació em sembla especialment adequada per a alguns dels exemples monumentals, provinents de portals d'esglésies, que estudia l'autora, però no crec que exhaureixi les possibilitats interpretatives en altres contextos. Laguna-Chevillotte estén aquesta interpretació, per exemple, a l'anomenat díptic de les Hores de Brussel-les (Bibliothèque Royale de Brussel-les, ms. I I060- I I06 I, f. I0-I I), una obra sobre la qual tornaré més endavant, $i$, en aquest $i$ altres casos, minimitza la importància de la presència del donant, la comunicació que s'estableix entre els personatges i el paper fonamental de Maria com a intercessora, la tipologia coneguda per la historiografia francesa com a Vierge à la supplique. Finalment, cal consignar que Vetter publicà el 2006 un nou recull generalista del tema, on incorporà alguns exemples no consignats per Parkhurst, entre els quals trobem dues de les obres catalanes que tractarem, malgrat que desconeix la procedència original d'un dels casos i, per tant, li falten importants elements per interpretar-ne el significat precís ${ }^{26}$.

A continuació examinarem tres exemples d'àmbit català on s'adapten variants o derivades d'aquesta iconografia. En primer lloc, una Mare de Déu amb el Nen que escriu procedent de la miniatura: l'única il-lustració coneguda del Levador del plat de pobres vergonyants, de Santa Maria del Mar de Barcelona, un códex desaparegut l'any 1936. En segon lloc, una Mare de Déu amb el Nen on Jesús no escriu, però sí que llegeix, que va ocupar un espai privilegiat en l'estructura d'un retaule, probablement com a taula cimera del de sant Jordi, de Bernat Martorell. I, finalment, una taula amb la Mare de Déu amb el Nen, sant Vicenç Ferrer i donants, on l'Infant no llegeix ni escriu, provinent també d'un moble d'altar, en aquest cas pintat per Pere Garcia de Benavarri. D'entrada, cal justificar la inclusió d'aquesta darrera imatge: si bé el Nen no escriu, sinó que estableix una conversa amb els donants per mitjà dels filacteris que uns $\mathrm{i}$ altres despleguen, el model iconogràfic emprat tant per la figura del Nen com pels donants i la Mare de Déu, així com les implicacions simbòliques derivades de la inclusió de sant Vicenç Ferrer i el propi destí del retaule, una capella funerària, permeten establir clares connexions amb altres imatges on el Nen sí que escriu i deduir una derivació d'aquestes imatges, tal com desenvoluparé en l'apartat corresponent.

\section{De la cort a la parròquia: \\ La importació d'un model de prestigi}

El primer exemple al qual em referiré ha estat posat en relleu diverses vegades, perquè resulta clau en l'estudi de la importació de les novetats, iconogràfiques $\mathrm{i}$ estilístiques, proposades per l'avantguarda artística francesa de cap al I 400 . Es tracta de la pàgina miniada d'un còdex, amb una imatge de la Mare de Déu entronitzada amb el Nen a la falda (figura 3). Jesús és, en aquest cas, un petit infant molt dinàmic, ocupat en l'escriptura del filacteri que sosté i en altres accions. Aquesta pàgina constituïa la portada o imatge inicial d'un manuscrit destruit o desaparegut en el curs de la Guerra Civil espanyola, el Levador del plat de pobres vergonyants, de l'església parroquial de Santa Maria del Mar de Barcelona. Malauradament, a causa de la seva pèrdua, només podem estudiar la imatge a través de les reproduccions fotogràfiques. La miniatura citada és, a part d'això, l'única publicada del còdex $i$, tot i que sembla que no en contenia cap més, no sabem si el llibre incloïa uns altres detalls que podrien haver estat interessants per establir-ne la filiació estilística i la interpretació iconogràfica ${ }^{27}$. 

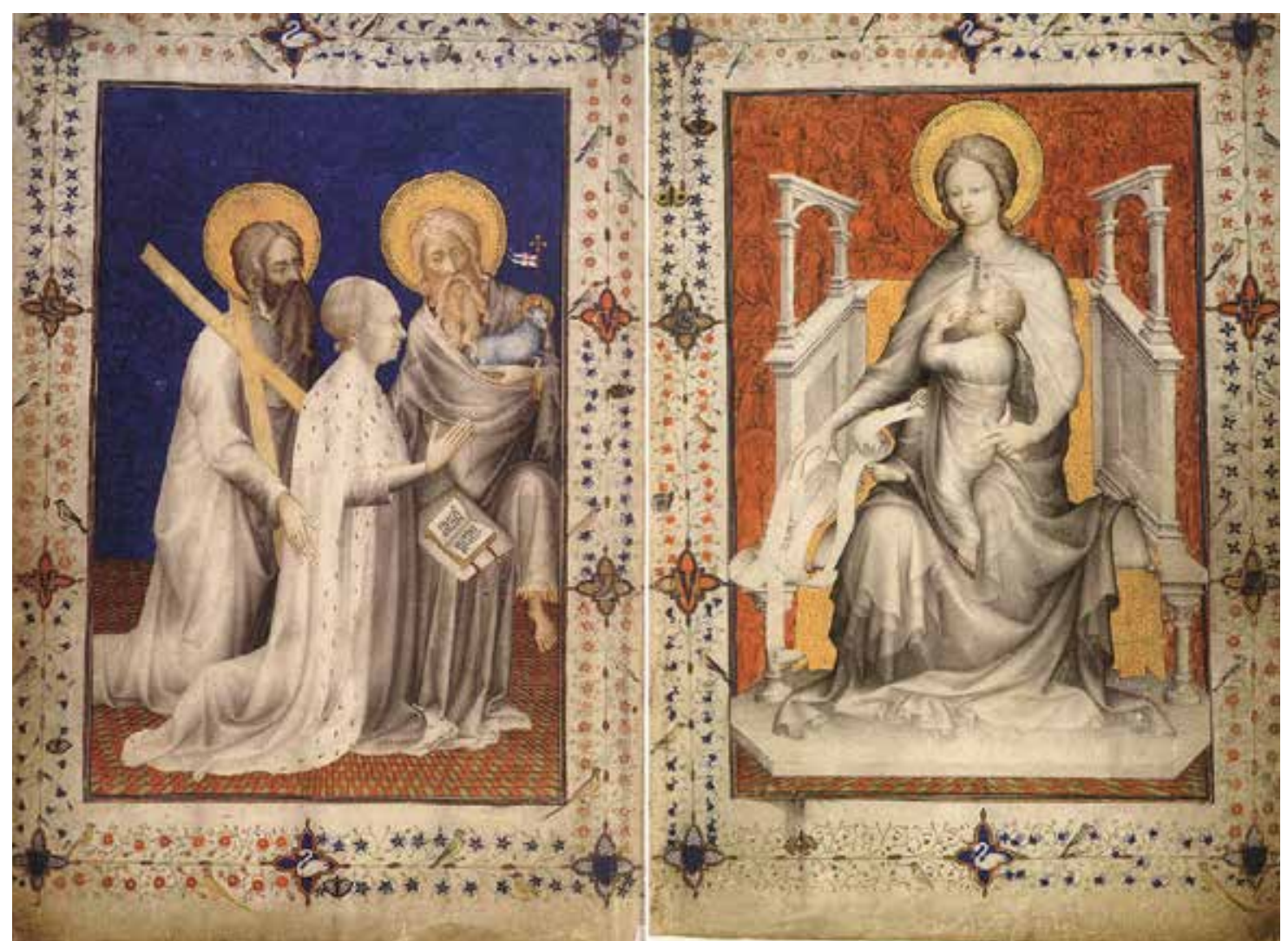

Figura 4.

El duc de Berry amb sant Andreu i sant Joan Baptista i la Mare de Déu amb el Nen que escriu, miniatura de Les Très Belles Heures du duc de Berry, Bibliothèque Royale de Brussel-les, ms. 11060-11061, f. 10-11.

Fou Millard Meiss qui situà aquesta imatge en el seu context creatiu general, tot analitzant-ne la connexió amb les marededeus amb el Nen escrivint de l'entorn de Joan de Berry ${ }^{28}$. L'historiador parla de dos subgrups d'aquesta iconografia que sembla que es creïn en el context artístic incentivat pel duc, amant i patrocinador de les arts, i que connecten, amb més o menys seguretat, amb el cercle de Jacquemart d'Hesdin. Un dels subgrups estaria encapçalat en l'actualitat - contemplant la possibilitat de l'existència d'una obra monumental, no librària, perduda - per l'esplèndid díptic que obre les anomenades Très Belles Heures $d u d u c d e$ Berry, també dites Hores de Brussel.les ${ }^{29}$ (figura 4). Malgrat que encara hi ha controvèrsia entre els historiadors al voltant dels diversos miniaturistes que es poden distingir al còdex, s'accepta, en general, que fou obra de Jacquemart d'Hesdin majoritàriament, atès que s'identifica $\mathrm{amb}$ un llibre d'hores miniat per aquest artista, ressenyat en un inventari del duc Joan de Berry de I 403 i entregat com a present al duc de Borgonya ${ }^{30}$. El díptic, això no obstant, potser no previst inicialment al programa decoratiu del llibre $i$ afegit més tard, s'exclou habitualment del catàleg d'Hesdin. En aquesta imatge a doble pàgina, Joan de Berry es presenta davant de la Mare de

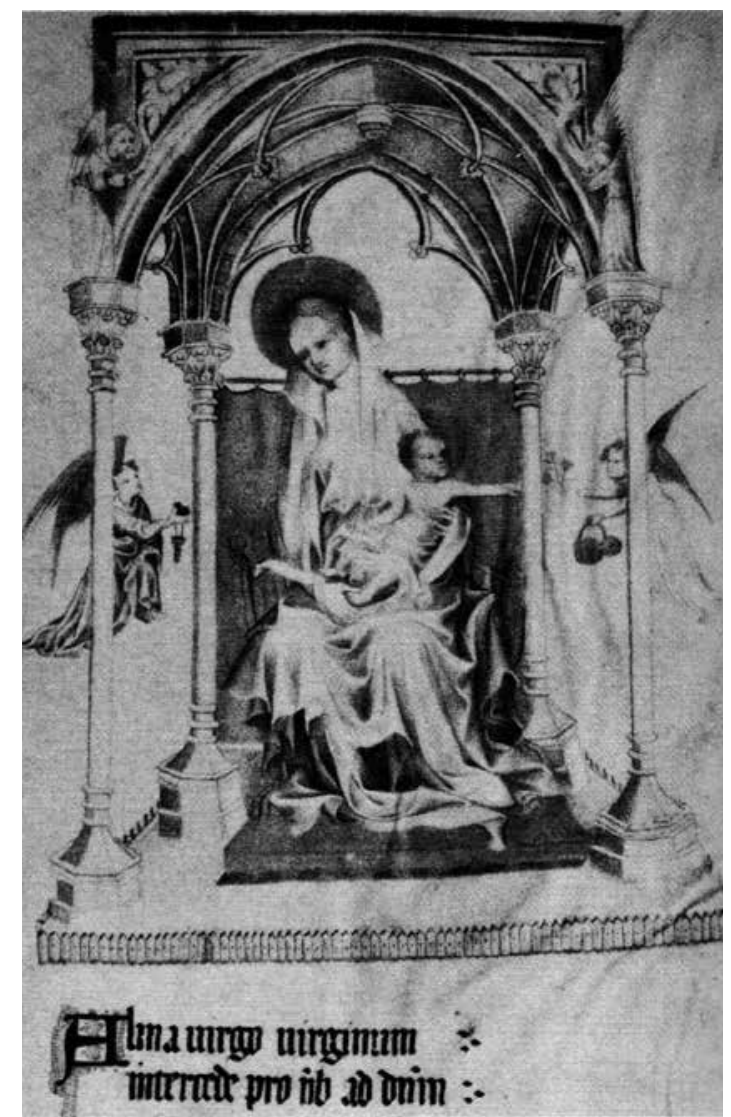

Figura 3.

Mare de Déu amb el Nen que escriu, miniatura del Levador del plat de pobres vergonyants, de Santa Maria del Mar, desaparegut. 


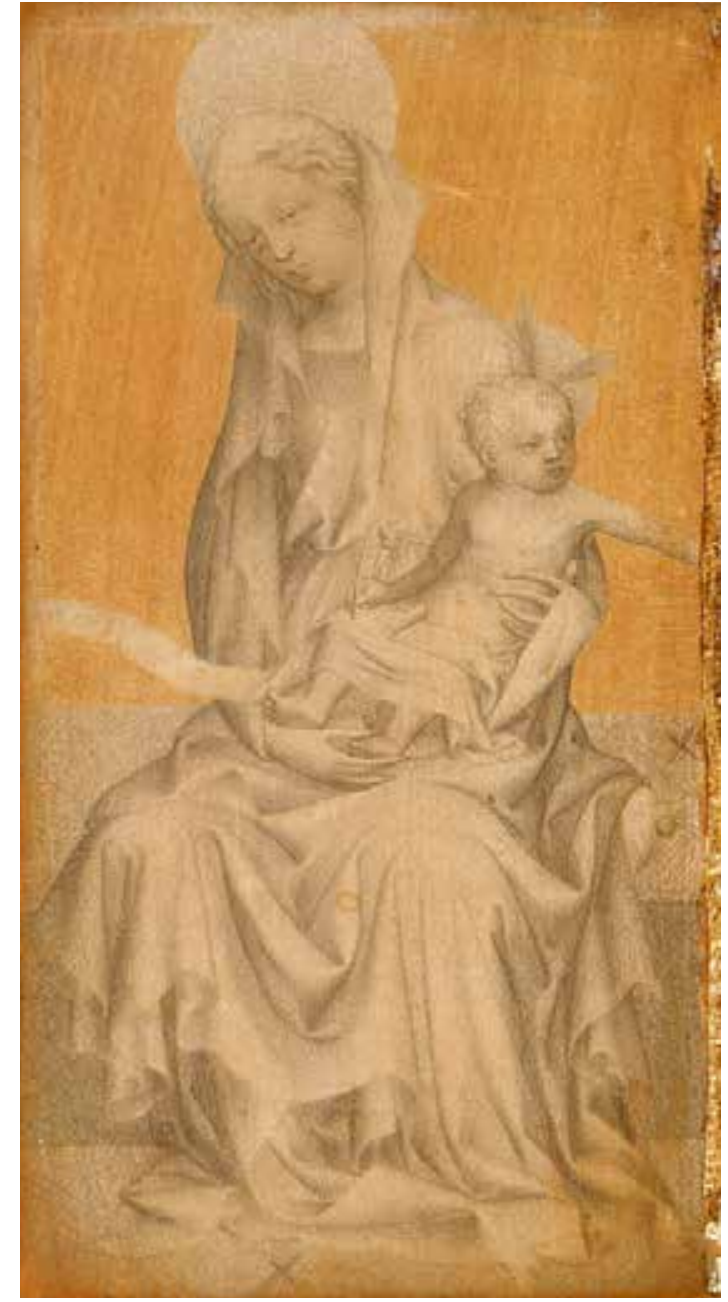

Figura 5.

Mare de Déu amb el Nen que escriu, dibuix sobre tauleta de fusta d'un llibre de models. Nova York, Pierpont Morgan Library, MS M.346, f. $1 \mathrm{v}$.

Déu, entronitzada i amb el Nen a la falda. Sant Andreu i sant Joan Baptista acompanyen el duc, que prega agenollat enfront d'un oratori on hi ha un llibre obert. En aquest còdex pintat s'hi llegeixen dos versicles extrets dels salms $50 \mathrm{i} 69$, on es demana reiteradament la misericòrdia i la salvació divina i que, a més, inauguren la litúrgia de matins i de les hores ${ }^{31}$. S'hi pot llegir «Domine labia mea aperies et os meum annunciabit laudem tuam» $i$ «Deus in adjutorium meum intende». El Nen, d'altra banda, atén a la vegada al pit de la seva mare, que l'alleta, i a un llarg filacteri en blanc, on amb tota probabilitat es disposa a escriure, segons la meva opinió, un missatge per al duc. Meiss connecta aquesta doble activitat del Nen amb algunes marededeus de la Humilitat sorgides dels pinzells de Simoni Martini o els seus seguidors, on el Nen gira el cap, sense abandonar el pit, per mirar de reüll el donant o l'espectador de l'obra. Tal com subratlla Meiss, aquesta iconografia no és privativa de la miniatura: en el camp escultòric destaca una deli- cada estatueta d'ivori conservada al Musée du Louvre (inv. OA 2745) 32 . En aquest cas no hi ha donant, però la gestualitat, els atributs de Maria $i$ el Nen i fins i tot el tractament del rostre i el treball dels plecs de les robes són molt similars $i$ obliguen a pensar en un mateix ambient creatiu. Parkhurst, a més de citar l'estatueta d'ivori com a paral-lel de la miniatura, es referia també a un relleu en pedra procedent d'un context votiu o funerari de l'església de Sant Andreu de Hildesheim, on es veu la doble acció de l'alletament i l'escriptura, a més d'un desplegament similar del filacteri. L'estudiós al-ludia, a més, a un brodat perdut que repetiria el tema i fins $\mathrm{i}$ tot potser la composició del díptic del llibre de Brussel-les, consignat a l'inventari de $\mathrm{I}_{4} 83 \mathrm{del}$ duc de Savoia ${ }^{33}$. Podia haver estat una obra similar a l'anomenat Tríptic brodat de Chartres, un brodat amb la imago pietatis, sant Joan Baptista i santa Caterina, disposat sobre tres tauletes de fusta a manera de petit tríptic portàtil, però hauria constat només de dues tauletes ${ }^{34}$. En el camp de la miniatura, tant Parkhurst com Meiss es refereixen a un exemple molt proper al de les Hores de Brussel-les, tot i que pintat per un altre artista, del taller del Mestre de Luçon, segons l'opinió de Meiss. Es tracta del foli 2 d'un altre llibre sorgit de l'entorn del duc de Berry, el manuscrit 926, de la BnF, on l'esposa del duc $\mathrm{i}$ la seva filla Maria preguen davant la Verge mentre aquesta alleta el Nen, que també escriu ${ }^{35}$. El llibre és un compendi de textos confegit cap al I 406 per a Maria de Berry sota les directrius de Simon de Courcy, el seu confessor. La miniatura, la primera del llibre, encapçala el text «Aiguillon d'amour diví». En aquest cas, donant i Nen comparteixen un únic filacteri, en el qual la primera expressa la seva pregària, tot dient $« \mathrm{O}$ mater dei memento mei», per continuar amb el parenostre, mentre el segon escriu «fiat». Ens interessa molt aquesta conversa directa i la seva resposta contundent com a paral-lel del que veurem en analitzar la taula de la Mare de Déu amb el Nen i sant Vicenç Ferrer, de Pere Garcia de Benavarri, i també perquè demostra que el llibre o filacteri compleix una doble funció: és un atribut de Crist com a Logos o Verb encarnat, però també un element de comunicació amb el donant ${ }^{36}$. Respecte a això, vull remarcar que l'exemple de Maria no és el primer on el prec del donant és atès d'una manera tan directa $i$ concreta. Les mateixes paraules, «O mater dei memento mei», i el mateix «fiat» confortaven ja el cardenal Pere de Luxemburg al seu llibre de pregàries, confegit probablement a París cap a I $386^{37}$. Una imatge molt similar es troba també al Llibre d'hores de Margarida de Clèves ${ }^{38}$, de cap a I 395-I 400. De nou es desplega un filacteri entre el donant agenollat i el Nen a la falda de 
Maria. L'Infant sembla escriure, mentre la Verge assenyala el text ja llegible al filacteri, que és l'inici del parenostre en llatí.

Malgrat els paralleles obvis pel que fa al context artístic $i$ el tipus iconogràfic d'aquestes peces, Laguna-Chevillotte afirmava que l'estatueta d'ivori del Louvre i el díptic «semblent servir des messages iconographiques différents» a la miniatura del llibre de Maria de Berry ${ }^{39}$. Ho creia en funció de l'absència de text als filacteris dels dos primers exemples, però, segons la meva opinió, desatén així uns altres elements iconogràiics, entre els quals destaca el caràcter de Virgo lactans de Maria, que reforça la seva capacitat intercessora en insistir en la seva connexió única amb el $\mathrm{Nen}^{40}$.

Tot i això, com ja hem vist al llibre de Pere de Luxemburg i al de Margarida de Clèves, l'alletament no és un motiu fix en aquest tipus iconogràfic. De fet, el segon subgrup de marededeus amb el Nen que escriu de l'entorn del duc de Berry definit per Meiss justament en prescindeix, de manera que el Nen té una gestualitat més lliure i natural: ja no ha de dividir la seva atenció entre el pit, el donant i el filacteri. A aquest segon subgrup pertany un dibuix exquisit, realitzat sobre una tauleta de fusta, que va formar part en origen, amb tota probabilitat, d'un llibre de models emprat en el context del taller artístic, avui conservat a la Pierpont Morgan Library, de Nova York (MS M.346, foli rv.) (figura 5). La Mare de Déu de la miniatura procedent de Santa Maria del Mar, tot i que també presenta connexions amb el díptic de les Hores de Brussel.les, sembla una versió d'aquest excel-lent dibuix o, potser, d'un altre exemple perdut ${ }^{41}$.

Tant al dibuix de la Pierpont Morgan com a la miniatura perduda, la Verge sosté el Nen sobre la seva falda, amb el braç esquerre, mentre li acarona suaument un peu, amb posat lleugerament absent. En contrast amb la melangia de la seva mare, Jesús és un petit infant molt desimbolt, nu a excepció d'un lleuger drap que creua per damunt de les seves cames. Té sobre els genolls un llarg filacteri, sosté amb la mà dreta l'estri per escriure i gira el tors allargant el braç esquerre. Al llibre de models el gest resta incomplet, atès que no hi ha cap més personatge ni objecte i, de fet, no es veu la mà esquerra del nen. Parkhust suggereix que l'esbós podia haver estat el model per a escenes on el Nen es gira per atendre els Reis Mags o per posar l'anell a santa Caterina. Així succeeix en un dels frontals brodats del conjunt de la capella del Toisó d'Or, on Jesús es distreu de l'escriptura, abandonant el filacteri sobre la seva falda, per entregar aquest símbol d'unió a la donzella i màrtir ${ }^{42}$. A la miniatura catalana, no obstant això, la solució és més simple: el Nen es gira vers un dels dos àngels que volen, una mica mancats de context, a dreta $i$ esquerra. Els àngels sostenen, respectivament, un tinter i un cistell amb flors, potser roses. L'autor de la il·luminació del Levador, d'altra banda, fa seure la seva Verge sobre una cadira de tisora, en el braç de la qual s'entortolliga el filacteri. Al dibuix del llibre de models el filacteri queda interromput, flotant de manera poc realista, la qual cosa fa pensar que en l'original perdut també es plantejava un tron o una cadira on reposés. Darrere de Maria penja un drap d'honor, agafat amb anelles a una barra horitzontal que se sosté entre les columnes del sumptuós baldaquí que cobricela Mare i Fill. L'estructura presenta carcanyols esculpits amb elements vegetals al frontis i quatre esveltes columnetes, sobre les quals s'aixequen àngels, sostenint una volta de creueria. Finalment, una petita tanca de fusta tot al voltant del baldaquí converteix l'espai en un bortus conclusus, com ja suggeria Meiss. Tot i aquests afegits, el tractament de les robes dels personatges és idèntic al del dibuix de la Pierpont Morgan: la Verge vesteix una túnica d'escot rodó cenyida a la cintura. Un ampli mantell rellisca descobrint-ne el cap parcialment i deixant-ne veure els cabells suaument ondulats, $i$ cau sobre les espatlles i els genolls en una profusió de plecs dinàmics de gran riquesa. És especialment decoratiu l'aspecte dels plecs en cascada del genoll dret de Maria a la miniatura del Levador $i$ al dibuix del llibre de models, treballats de manera molt similar al díptic de Brusselles. També resulta proper, en els tres casos, la manera com un plec d'aquest mantell s'entortolliga al coixí o a la cadira de Maria. Meiss assenyalava un altre detall que comparteixen el dibuix sobre taula i la miniatura de Santa María del Mar amb algunes de les miniatures principals de les Hores de Brussel-les: la particular figuració del nimbe del Nen, parcialment ocult darrere del cos de Maria. El dibuix del llibre de models i el díptic de les Hores tenen en comú, a més, el seu tractament a manera de grisalla. Meiss afirma que la miniatura de Barcelona també era una grisalla, però, per contra, Bassegoda parla clarament d' «una hermosa portada en or y colors representant la Madona y el Bón Jesus $\mathrm{ab}$ un àngel a cada banda del faldistori $[\ldots] »^{43}$. Les fotografies en blanc i negre no ajuden a dirimir la qüestió, però, en el cas que a la miniatura de Barcelona s'hagués emprat la grisalla, o potser una gamma atenuada de colors, hauríem de pensar en una connexió encara més forta amb el llibre de models i el díptic de Brussel-les, més que no pas en la veneració de Notre-Dame-la-Blanche, com suggereix Meiss ${ }^{44}$.

La desaparició del còdex ens impedeix realitzar-ne una anàlisi estilística i codicològica aprofundida, però les entrades de la primera pàgina permeten llegir amb molta claredat la data de I $43 \mathrm{I}^{45}$, la qual cosa ens situaria, com ja ha estat remarcat, dècades més tard de la cronologia pro- 
posada per al model, que se sol datar cap al I400, abans, en tot cas, de la redacció de l'inventari de I 403. Resulta molt interessant remarcar la vinculació d'aquesta Mare de Déu no només amb el dibuix de la Pierpont Morgan, sinó també amb el díptic de les Hores de Brussel-les, perquè, a més, en el context català, l'únic altre exemple de còpia literal d'un model francès del gòtic internacional que per ara s'ha identificat es relaciona amb el mateix llibre. Joan Antigó versiona, al Retaule de la Mare de Déu de l'Escala, del monestir de Sant Esteve de Banyoles, la presentació al Temple, del foli $98^{46}$. Aquest retaule també ens situa a la dècada dels anys trenta del segle Xv, cap al I437-I439, la qual cosa ens ha de fer reflexionar sobre quins artistes i quins models circulaven en aquestes dates a Catalunya ${ }^{47}$.

Cal esmentar l'existència d'una tercera versió del dibuix de la Pierpont Morgan: es tracta d'una miniatura conservada a la Stiftsbibliothek de St.

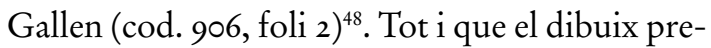
senta el mateix aspecte incomplet que el del llibre de models (sí que s'hi veu la mà esquerra del Nen, però n'ha desaparegut qualsevol insinuació de la cadira o del tron de la Verge i el filacteri es desplega en el buit), el seu estil és molt menys fidel al cercle de Jacquemart d'Hesdin que la miniatura catalana. La Verge ha perdut la seva actitud melancòlica i pensativa i somriu despreocupadament mentre el Nen sembla que vulgui escriure sobre el filacteri, però no ostenta ja cap estri per fer-ho. Els trets són, en general, més grollers.

Hi ha un aspecte en el qual divergeix, d'altra banda, la versió catalana de les dues altres: ni al dibuix sobre taula ni a la miniatura de St. Gallen no hi ha res escrit als filacteris. Al manuscrit de Barcelona, en canvi, sí que s'hi distingeixen algunes lletres, tot i que no és possible desxifrar-ne el missatge, almenys a partir de les fotografies que n'he pogut consultar. Falta, això sí, un destinatari explícit de les paraules del Nen: no s'ha representat el donant, com veiem al llibre de pregàries de Pere de Luxemburg, a les Hores de Joan de Berry, al llibre de la seva filla Maria o al de Margarida de Clèves. En aquest punt és rellevant parlar, ni que sigui breument, de la tipologia del llibre on s'inclou la miniatura. No es tracta d'un llibre d'hores, un breviari, un saltiri o algun altre tipus de compendi confegit a la mida del seu destinatari, pensat per a la pregària individual d'un personatge $i$ la seva ostentació social. Aquests acostumen a ser els còdexs més rics $\mathrm{i}$ amb un aparell de miniatures més extens i personalitzat de la baixa edat mitjana, i la iconografia que ara analitzem troba el seu sentit més complet en aquest context. En aquest cas, però, no es tractava d'un llibre de luxe i pietat personal, sinó d'un còdex destinat a consignar la gestió de la caritat que feia el Plat de la par- ròquia de Santa Maria del Mar, una entitat laica, tot $\mathrm{i}$ estar adscrita a la institució eclesiàstica ${ }^{49}$, que es dedicava a atendre els anomenats «pobres vergonyants», una categoria ben específica que englobava aquells que no ho eren de naixement, sinó que havien caigut en aquest estat en el curs de la seva vida a causa d'alguna adversitat, i, per aquesta raó, eren auxiliats de manera diferent i més «discreta». El cas és que la imatge no inclou, tal com la coneixem, cap figura que alludeixi a aquests pobres ni als seus benefactors, però a la part baixa s'hi pot llegir: "Alma virgo virginum, intercede pro nobis ad dominum» ${ }^{50}$. Aquesta frase consta entre les benediccions que precedeixen la lectura dels oficis de matines de la Verge, segons es comprova en diversos llibres d'hores, breviaris i missals dels segles XIV i $\mathrm{Xv}^{51}$. Tot i l'absència de la representació del donant que ens permeti assenyalar un interlocutor directe del Nen i un beneficiat de la intercessió mariana, em sembla evident que la conjunció de la imatge i l'oració a la pàgina inicial del llibre ens permet encabir aquest exemple dins de la categoria definida com a «Vierge à la supplique».

Si el que es volia era representar la protecció de la Verge sobre el col-lectiu es podia haver optat per unes altres iconografies que van atènyer una gran popularitat al llarg dels darrers segles de l'edat mitjana, com ara la Mare de Déu de la Misericòrdia, especialment apropiada en el cas d'imatges destinades a confraries o grups. Tot i que habitualment es representa dempeus, acollint sota el seu mantell aquells que demanen la seva protecció, en alguns casos, com al compartiment cimer del retaule de sant Vicenç, de Menàrguens (ca. I438-I440, MNAC), de Bernat Martorell, s'hi representa també entronitzada. I, malgrat que en l'àmplia majoria dels casos apareix sense l'Infant, hi ha exemples on sí que s'hi inclou, fins $i$ tot alletant-lo, com al compartiment principal del singular Retaule de la Mare de Déu de la Llet, d'Antoni Peris, probablement anterior a I4 I $5^{52}$. En l'adopció d'aquesta iconografia degué pesar, sens dubte, la suggestió que exercí la disponibilitat d'un model forà $\mathrm{i}$ «de prestigi». Però és probable, també, que es volgués concedir al Nen un paper específic i destacat, contraposat al de Maria.

Mentre la Verge és intercessora, sembla clar que podem considerar l'Infant el Jutge que dicta (i escriu) la sentència, no tant potser sobre els pobres vergonyants auxiliats a la parròquia com sobre aquells que donen rendes al Plat amb les quals es portarà a terme l'acció caritativa. És el jutge també dels administradors, que havien de regir amb rectitud l'ús dels recursos obtinguts pel bací i que, segons sembla, no havien de retre comptes a ningú més. Davant de l'Infant juganer $\mathrm{i}$ despreocupat, que fins $\mathrm{i}$ tot abandona la 
seva tasca per atendre l'oferiment dels àngels però que no deixa de ser Jutge i Senyor, aquesta Maria un pèl capficada és la mare consirosa pel destí dels seus fills, i també potser la imatge simbòlica de l'Església, que forneix l'ocasió i l'espai per practicar la caritat $i$ altres virtuts, ens ensenya el camí recte $\mathrm{i}$ intercedeix per nosaltres.

$\mathrm{Ni}$ el prec ni la imatge estan fora de lloc en un llibre administratiu: recordem que qualsevol contracte s'iniciava amb una invocació a la divinitat, la Verge o els sants. És avinent també aquí citar la miniatura inicial del Llibre de capbreus o Aplega de capbreus dels emfiteutes que presten censos als aniversaris comuns del Capitol de la Catedral de Barcelona, conservat a l'Arxiu de la seu. Aquest llibre de caràcter utilitari s'obre amb una invocació a la Mare de Déu i a santa Eulàlia i s'il.lustra amb una esplèndida figura de la verge màrtir $\mathrm{i}$ «cos sant» de Barcelona, obra amb tota probabilitat de Rafael Destorrents ${ }^{53}$.

Una iconografia nascuda, doncs, als tallers parisencs del darrer quart del segle XIV, amb notable èxit en l'ambient cortesà que envoltà Joan de Berry, es trasllada, sense perdre el sentit ni l'eficàcia, al context d'una organització assistencial adscrita a una parròquia barcelonina. Una imatge que en origen materialitza la conversa entre el fidel particular i la divinitat, l'angoixa per la salvació personal i el destí de l'ànima, es trasllada a un diàleg i a un context que implica la comunitat $\mathrm{i}$ les pràctiques caritatives. Al llibre de pregàries del cardenal Pere de Luxemburg, a les Hores de Brussel-les, al compendi de Maria de Berry i al Llibre d'hores de Margarida de Clèves el fidel s'enfronta al seu destí, Crist és jutge. La fórmula escollida, però, lluny de desplegaments majestàtics i apocalíptics, permet insistir tant en la preocupació humana pel seu destí final com en l'Encarnació i, doncs, en Maria Mediatrix. En tots els casos és Maria la interpel·lada, però és l'Infant qui contesta, tant si ja ha escrit com si es disposa a escriure. Finalment, m’interessa remarcar el transvasament de la iconografia d'un àmbit privat a un altre que implica la comunitat, atès que el segon exemple vers el qual dirigirem la nostra atenció s'insereix en un context institucional i ens trasllada, a més, de la miniatura a la retaulística, és a dir, a un context monumental, públic.

\section{La Saviesa i la Humilitat, font de les virtuts}

En aquest segon exemple, com avançava, el Nen no escriu, tot i que sí que llegeix (figura 6), i potser per això no ha estat tingut en compte en els articles que s'han ocupat del tema, amb l'excepció de Vetter, l'any 2006. L'obra en qüestió és una pintura sobre taula de roure que va pertànyer,

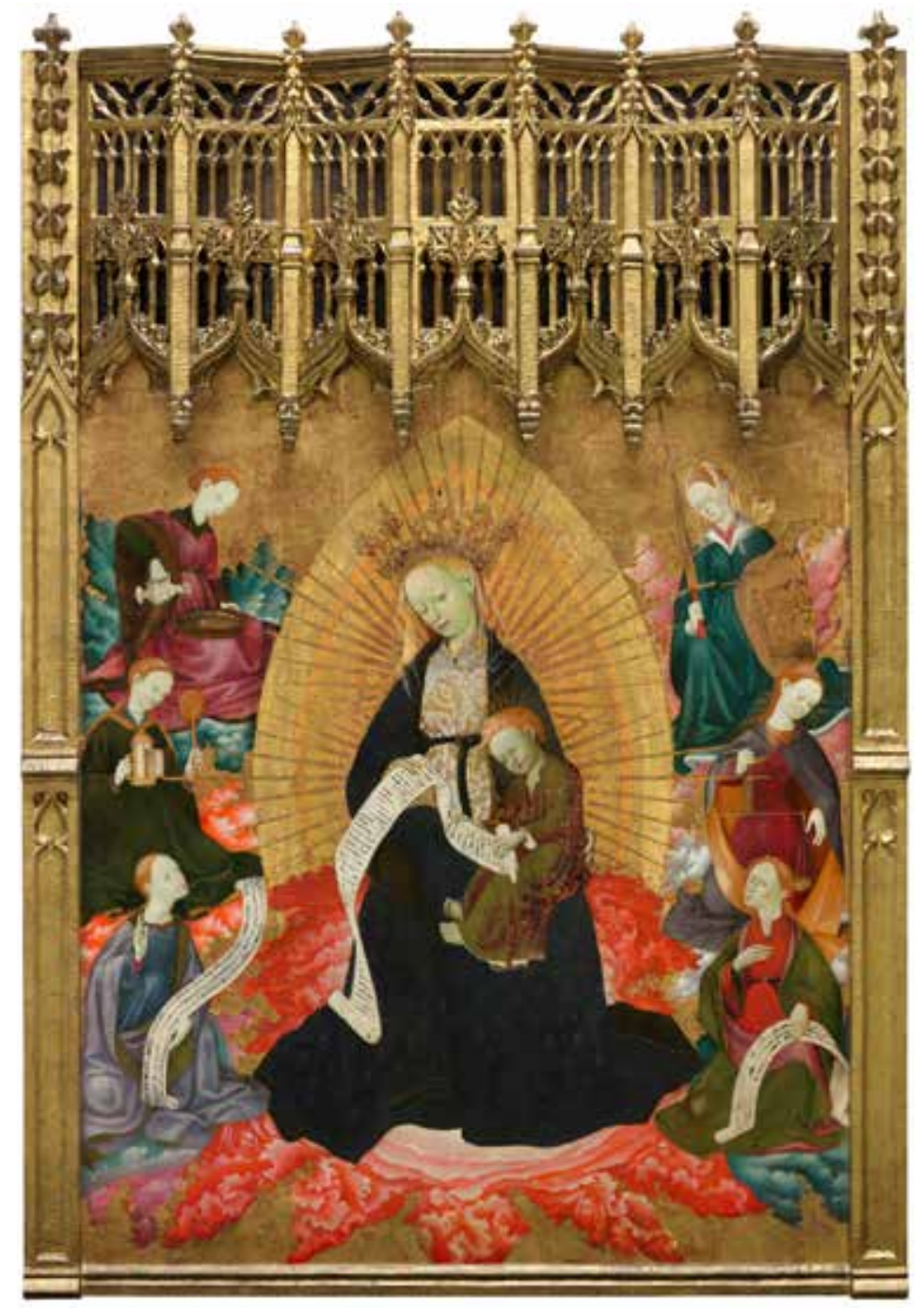

Figura 6.

Bernat Martorell, Mare de Déu amb el Nen, virtuts cardinals i altres figures, probablement taula cimera del Retaule de sant Jordi, de la Generalitat. Philadelphia Museum of Art (inv. 759).

en origen, a un retaule. Actualment es conserva al Philadelphia Museum of Art (inv. 759), on va ingressar com a part de la col·lecció John G. Johnson el I9I7, i això és tot el que sabem amb certesa, per ara, del seu periple. Tot $\mathrm{i}$ una certa diversitat d'opinions, sembla que actualment hi ha consens en considerar-la una obra de Bernat Martorell ${ }^{54}$, tal com ja va proposar Ch. R. Post el I $94 \mathrm{I}^{55}$. S'aprecien algunes refeccions i repintats, especialment en els rostres de les dues figures femenines de la part inferior, però tant la factura pictòrica com els tipus fisonòmics de la Mare de Déu, el Nen i les figures femenines de la part superior concorden a la perfecció amb l'estil de les obres de Martorell d'inicis de la dècada dels anys trenta. De fet, la peça va pertànyer, amb tota probabilitat, a una de les seves obres mestres d'aquesta etapa, el Retaule de sant Jordi, de la capella de la Casa de la Diputació del General de Catalunya a Barcelona, construïda entre I432 
i I $436^{56}$. La taula comparteix amb el conjunt hagiogràfic que va presidir la capella de la Generalitat l'excepcionalitat del suport, fusta de roure, indicador d'un encàrrec important per part d'un comitent disposat a pagar-ne la importació des del Bàltic. També les mides ( $54 \mathrm{~cm}$ x $107 \mathrm{~cm}$ ), l'estil i la iconografia permeten defensar la connexió amb les taules avui servades al Louvre i a Chicago. Tal com he exposat junt amb Rafael Cornudella en altres publicacions, els seus vincles amb el conjunt de la Generalitat s'imposen prou com perquè puguem descartar propostes anteriors amb força seguretat. És el cas de la hipòtesi de Post, que pensava que podia haver estat un dels compartiments del retaule encarregat el I 427 per la confraria dels freners a Martorell, destinat a l'església de Santa Maria de Jesús de Barcelona i, sobretot, de la proposta de Mary Grizzard, fonamentada en una lectura errònia de la documentació conservada a l'Arxiu de la Corona d'Aragó, que suggeria que la taula podia haver estat part del retaule comissionat pels diputats amb motiu de les Corts Generals de Montsós7.

En síntesi: fou Claudie Ressort qui va fer notar per primera vegada que, al catàleg de l'exposició retrospectiva d'art organitzada el I 867 per l'Acadèmia de Belles Arts de Barcelona, s'hi consignen les cinc taules amb la història de sant Jordi conegudes (actualment, les quatre taules laterals es troben al Louvre, i la central, a l'Art Institute de Chicago) al costat d'una sisena, una taula amb la Mare de Déu propietat del mateix col-leccionista, Francesc de Rocabruna. Ressort proposà que aquesta taula mariana, que ella creia potser perduda o, almenys, sense identificar, podia haver constituït el coronament del conjunt. Més tard, Santiago Alcolea va identificar aquesta taula dels Rocabruna amb la Mare de Déu amb el Nen i virtuts, de Filadèlfia, i en defensà la pertinença al conjunt hagiogràfic ${ }^{58}$.

La taula que ara ens ocupa està protagonitzada per una elegant Mare de Déu, abillada amb una túnica blanca de brocat daurat i coberta amb un mantell blau. Un subtil vel transparent cau sobre els cabells rossos, sota una sofisticada corona d'or ornada amb perles i pedres i rematada amb alts florons. La Verge es presenta asseguda sobre un cúmul de núvols rogencs esquitxat de caparrons angèlics, en una particular adaptació de la postura de la Mare de Déu de la Humilitat $\mathrm{a}$ un àmbit transcendent, lluny de qualsevol dels escenaris propis de la infància de Crist ${ }^{59}$. La seva figura apareix aureolada per una màndorla recorreguda per rajos solars que remet a la imatge apocalíptica de la Dona perseguida pel drac (Apocalipsi I 2,I-6), una figura polisèmica que s'identifica progressivament, al llarg de l'edat mitjana, amb l'Església i la Mare de Déu. Exegetes com ara Hipòlit de Roma (segle II) o
Beda el Venerable (segle viI) l'identificaren amb l'Església, mentre que d'altres, com ara el bisbe de Cartago Quodvultdeus (segle v), inicien ja el camí de la vinculació mariana ${ }^{60}$. Serà, però, a partir del segle XII quan prendrà més importància la connexió teòrica $i$ visual de la Dona apocalíptica amb Maria i quan els comentaristes superin la dificultat que plantejava el text, que al-ludeix als dolors de l'infantament d'aquesta Dona, vinculant-los, no al part virginal i sense patiment de Maria, sinó al seu plany a la creu on va morir Crist. Un cop establerta la relació entre la Dona apocalíptica i la Mare de Déu, la seva iconografia es desenvolupa seguint una doble via: de vegades la Dona apocalíptica es representa com Maria en el context narratiu de l'Apocalipsi; d'altres vegades és la Verge qui incorpora alguns elements de la visió de sant Joan en contextos plens de referències escatològiques, però que no constitueixen una il-lustració del relat de la fi dels temps.

A la taula de Filadèlfia tant la postura sedent com els símbols apocalíptics concorden amb la iconografia de la Mare de Déu de la Humilitat, però en aquest cas es prescindeix d'un tercer element habitual: l'alletament. Maria sosté sobre el genoll esquerre el Nen, representat de perfil i abstret en la lectura d'un llarg filacteri que la Mare l'ajuda a sostenir. Jesús no sembla un petit nounat, sinó un nen d'uns dos o tres anys, vestit amb una túnica llarga de color verd oliva amb brocat daurat que li descobreix els peus. De cabells rossos i arrissats, com la Verge, el Nen presenta trets delicats i dolços, però també una expressió solemne i seriosa impròpia, com l'activitat que desenvolupa, de la seva curta edat. Alguns dels elements de la taula de Filadèlfia concorren en un altre compartiment de retaule que ja ha estat citat en estudis anteriors com a referent a l'hora de justificar la pertinença d'una taula mariana en un context hagiogràfic ${ }^{61}$. Es tracta d'una de les taules cimeres del Retaule de sant Jordi del Centenar de la Ploma (Victoria \& Albert Museum, Londres). En aquest cas, la iconografia apocalíptica i l'alletament es conjuguen amb la Mare de Déu entronitzada i a punt de ser coronada per la Trinitat, acompanyada de tota una cort angèlica ${ }^{62}$.

A la pintura de Martorell, d'altra banda, mare $i$ fill es presenten acompanyats per sis figures femenines, la iconografia de les quals ja ha estat discutida abans. Sembla clar que les quatre figures superiors representen les quatre virtuts cardinals (la Prudència, la Justícia, la Fortalesa i la Temprança), atès que s'acompanyen dels atributs respectius. La Temprança aboca aigua d'una gerra ceràmica en un recipient de metall daurat; la Fortalesa, al seu torn, enarbora una espasa amb la mà dreta mentre sosté l'escut amb l'esquerra; la Prudència du a les mans un mirall 
i un fanalet, i la Justícia sosté les tradicionals balances. És molt plausible que les dues figures inferiors, que despleguen llargs filacteris però no porten cap altre atribut, siguin sibilles, com ja va suggerir Post i ha elaborat àmpliament, en dates més recents, Rosa Alcoy ${ }^{63}$. Tot i això, no podem descartar que es tracti d'altres conceptes "positius» associats al bon cristià i al bon govern. L'artista ha combinat sàviament els tons de les nuvolades sobre les quals seuen o s'agenollen les dones i la Verge, de qui varia també les robes $i$ els pentinats afegint ritme a l'escena. En els darrers anys (2015) el museu ha dotat la peça d'un nou marc, retirant l'antic motlluratge amb tres gablets, igualment postís. Aquests tres gablets, que no s'adeien en absolut amb l'estructura pròpia dels emmarcaments dels retaules catalans medievals, deixaven veure al centre, gràcies a la seva traceria calada, un colom que, segons les informacions de Carl B. Strehlke, no és original ${ }^{64}$.

Tot i que, segons Millard Meiss, la Mare de Déu de la Humilitat en sentit estricte és la que inclou no només la postura sedent a terra de Maria, sinó també l'alletament del Nen i els símbols apocalíptics, les combinacions, com ell mateix admet, són molt variades. D'altra banda, la taula de Filadèlfia encaixa molt bé amb la interpretació que fa l'historiador de la Mare de Déu de la Humilitat com a font i origen de les virtuts ${ }^{65}$. Com ell indica, la Humilitat no troba el seu lloc entre les virtuts teologals ni cardinals (tot $\mathrm{i}$ que es pot vincular amb la Temprança), però és l'arrel de totes les virtuts. En un joc de contraris molt propi del gust medieval: Maria, la més humil, «l'esclava del Senyor», fou la més enaltida, l'única Reina dels Cels. M'interessa remarcar l'adopció de la postura de la Mare de Déu de la Humilitat, perquè l’àmplia majoria de les Verges amb l'Infant que escriuen o llegeixen es presenten, com hem vist fins ara, entronitzades o dempeus. És, per tant, significatiu que aquesta Maria, que no deixa de ser reina, com proclama la seva alta corona, segui a terra, en un esquema que ens parla de la seva gran virtut com a origen o arrel de les altres virtuts. Un altre exemple amb Maria asseguda a terra es troba entre els publicats per Vetter ${ }^{66}$. Es tracta d'una taula procedent de l'església de Sant Llorenç de Nuremberg, de cap a I437, on Maria, de nou coronada, seu en un jardí, flanquejada per dos sants i acompanyada per àngels que sostenen un drap d'honor. A la part inferior s'agenollen els donants, un tal Heimrich Gärtner i la seva família. Sembla que la peça fou encarregada amb motiu de la defunció del personatge, i el context funerari i escatològic ens convida a interpretar el jardí on seu Maria com un espai ultraterrè, paradisíac, $i$ aquest Nen que escriu també com a Jutge.

Jutge és, em sembla clar, l'Infant de la taula de Martorell. L'àmbit transcendent ens situa fora del temps i de l'espai - potser en un moment en què el temps ha finit i l'espai s'ha de redefinir- en un context apocalíptic, de Judici Final. Crist no s'adreça a cap donant ni tampoc interactua amb la seva Mare ni ens envia un tranquil-litzador missatge de final feliç, com succeïa en alguns dels manuscrits citats. Per contra, sembla que busqui amb afany un passatge concret de la revelació o bé els noms dels benaurats inscrits al Llibre de la Vida. L'Antic Testament està esquitxat de referències al llibre on la divinitat apunta o esborra els noms dels seus escollits. Es troben tant a l'Èxode (32,3I-33) com als llibres profètics de Malaquies o Daniel (Malaquies 3,I6-17; Daniel I $2, \mathrm{I} ; 7,9-1$ - $\mathrm{O}$ ) que foren tinguts en compte al llarg dels primers segles del cristianisme i més tard en la construcció de l'imaginari apocalíptic i en la seva exegesi. El Nou Testament continua amb aquesta tradició de metàfores bibliòfiles, molt especialment a l'Apocalipsi (3,5; 20,15; 21,27; 22,I8-19), però també a l'evangeli de sant Lluc $(\mathrm{I} 0,20) \mathrm{i}$ a les epístoles (Filipencs 4,3). A l'Apocalipsi $(3,5)$ s'hi llegeix, per exemple: «Qui vicerit, sic vestietur vestimentis albis, et non delebo nomen ejus de libro vitæ, et confitebor nomen ejus coram Patre meo, et coram angelis ejus».

Maria ja no alleta aquest petit Jutge, però l'acompanya $\mathrm{i}$ és present en el desplegament del filacteri, deixant clar quin és el seu paper, la seva participació en el pla de salvació humana. Aquest tipus de Mare de Déu amb l'Infant que sosté un llibre sembla, de fet, en el seu sentit més pur, una actualització de la Sedes Sapientiae romànica al tarannà del gòtic internacional. Respecte a aquesta qüestió, Mary McDevitt cita el títol que Guerric d'Igny († I I 57) adjudica a Maria: «Thronus ad iudicandum», que, com la mateixa autora indica, no és més que una variant de Sedes Sapientiae ${ }^{67}$. En aquest context de Judici la idoneïtat de la representació de les Virtuts podria no necessitar una gran justificació. Està clar que la seva pràctica (com la de la caritat en l'auxili als pobres) és imperativa per als fidels cristians $i$ afavoreix, tot $i$ que no assegura, un bon resultat el dia de la sentència. La pràctica de la Justícia, la Prudència, la Temprança i la Fortalesa, d'altra banda, sembla especialment escaient en un retaule destinat a una institució de govern, com ja hem remarcat en publicacions anteriors. Voldria, a més, recordar que a la façana renaixentista del Palau de la Generalitat s'esculpeixen també les virtuts: dues de teologals, la Fe i la Caritat, i dues de cardinals, la Justícia i la Prudència ${ }^{68}$. Finalment, són diversos els textos bíblics que estableixen el vincle entre la Saviesa (Déu) $i$ les virtuts cardinals. Així succeeix, per exemple, al llibre Saviesa $(8,7-8)$, on sembla que s'hi derivin ${ }^{69}$.

Recordem ara que el vincle explícit entre la iconografia de la Mare de Déu amb el Nen i el 
llibre i la Saviesa glossada a l'Antic Testament es materialitzava a la inscripció del setial de la Mare de Déu de Claus de Werve procedent de Poligny i conservada al MET, en aquell cas amb una citació de l'Eclesiàstic.

Resulta interessant com a paral-lel parcial, i sense proposar cap tipus de vincle directe entre les obres, una pintura sobre taula de The Cleveland Art Museum atribuïda a Olivuccio di Cicarello (I360/1365-I439, inv. I916.795), un pintor de les Marques, actiu a Ancona, on va morir ${ }^{70}$. L'obra inclou en aquest cas tots els ingredients definits per Meiss com a propis de la Mare de Déu de la Humilitat i alguns més: la Verge seu en un coixí $i$ alleta el Nen, que es gira per connectar amb l'espectador. Als peus de Maria es pot veure la lluna i dotze estels radiants orlen el seu cap, incloent els bustos dels dotze apòstols. Un sol en relleu de guix daurat presideix la cantonada superior esquerra. Hi ha, a més, un compartiment inferior on jeu Eva, acompanyada de la serp i amb la poma a la mà, que aixeca els ulls cap a la seva contrafigura amb una expressió eloqüent. La Verge, d'altra banda, està acompanyada per tres personatges que s'han identificat com sant Jordi i els arcàngels Gabriel i Miquel. En el cas de Gabriel, agenollat davant de Maria amb el seu Infant com qui constata el resultat tangible de l'Anunciació, les ales multicolors no deixen espai a dubtes sobre la seva qualitat angèlica. La identificació de les altres dues figures és també plausible: el personatge inferior de la banda dreta ostenta les armes pròpies del cavaller sauròcton, un escut amb la creu vermella i una espasa, mentre que el personatge superior porta unes balances i enarbora també una espasa que poden fer referència al paper de sant Miquel en el judici de les ànimes i a la lluita contra els àngels rebels que encapçala com a capità dels exèrcits celestials. Tot $i$ això, aquesta darrera figura no porta ales, la qual cosa és poc habitual. Pel seu paper en el Judici Final i en el combat amb la bèstia apocalíptica, sant Miquel és un bon company de la Verge amb els atributs de la Dona Apocalíptica. Sant Jordi és un altre sant que deslliura una dona, i tot un regne, del setge d'una bèstia malèfica i redundaria, doncs, en el mateix missatge. El que em sembla, però, interessant, és la similitud de la formulació plàstica de sant Jordi i sant Miquel amb la Justícia i la Fortalesa de la taula martorelliana, remarcada per la qualitat àptera de sant Miquel.

Recordem que l'àmbit transcendent $i$ alguns dels atributs apocalíptics, junt amb una postura de la Verge propera a la de la «humilitat», concorrien al tondo de la Walters Art Gallery que he citat més amunt, $\mathrm{i}$ també allà es prescindia de l'alletament (figura 2). El nimbe de Maria en aquest tondo inclou la salutació angèlica, una referència que reforça el sentit encarnacional de la imatge.
Els anyells que decoren, com blasons heràldics, el drap d'honor sostingut per àngels complementen el missatge amb la seva referència al sacrifici ${ }^{71}$. L'escriptura, la lluna a manera de setial de Maria i fins i tot la divisa repetida al marc, «je suis bien», insisteixen en les referències escatològiques.

Resulta també interessant per la similitud dels elements que integra, tot i que és molt posterior a la taula de Martorell, el compartiment central d'un retaule pintat per Lucas Cranach cap a I 529. En aquest cas Maria seu sobre el creixent de lluna, sobre un fons d'or, aureolada per núvols habitats per àngels. El Nen sosté un llibre, tancat en aquesta ocasió, $i$ es dirigeix al donant, el cardenal Albrecht de Brandenburg, agenollat sobre un coixí enmig d'un paisatge ${ }^{72}$.

Com succeïa amb la Mare de Déu amb el Nen escrivint, la imatge de Maria acompanyada per l'Infant amb el llibre materialitzat a la taula de Martorell presenta també nombroses variants que impliquen matisos de significat. En el context català destaca un altre exemple vinculat a la retaulística, tot i que pertanyent al camp de l'estatuària. Es tracta de la Mare de Déu amb el Nen que va presidir el retaule major de l'església cistercenca de Santes Creus, atribuïble a Antoni Canet ${ }^{73}$. Aquest retaule de factura i d'història complexes, que involucra els tallers de Pere Serra, Guerau Gener i Lluís Borrassà, i que conservem actualment distribuït entre el Museu Diocesà de Tarragona i el MNAC (a més d'alguna peça de la predel-la en collecció particular), incorporava la particularitat de combinar escultura i pintura. Les escenes narratives pintades, dedicades als Goigs de la Mare de Déu, amb especial atenció al seu gloriós final, s'arrengleraven a banda i banda d'una talla de Maria amb el Nen de mida lleugerament superior al natural $(202 \mathrm{~cm}$ d'alt), mentre que, a tots dos laterals, es disposaven les imatges de sant Benet i sant Bernat, especialment escaients en el context d'un retaule destinat a un monestir cistercenc. La Mare de Déu es presenta dempeus, vestida amb una túnica de brocat daurat visible només en part a causa del mantell que li cobreix el cap i que li embolcalla el cos. Sobre el mantell du una corona d'alts florons i a la mà dreta porta encara la tija de les flors que devia sostenir originàriament. L'Infant seu sobre el braç esquerre de Maria, i, com el Nen de Martorell, es tracta d'una criatura d'un parell d'anys, vestida amb una túnica també de brocat, que sosté amb la mà esquerra un llibre obert, un full del qual assenyala amb el dit índex de la mà dreta. Els cabells rossos i arrissats i els trets dolços, amb les galtes inflades, de la figura infantil, són uns altres punts de contacte amb el compartiment pintat de Filadèlfia. Fou Trens qui primer va cridar l'atenció sobre la peculiaritat de l'atribut de la talla ${ }^{74}$, que, això no obstant, no és tan sorprenent si ens 
situem en el context del gòtic internacional i recordem l'abundància d'exemples monumentals d'aquest tipus al llarg de les dues darreres dècades del segle xiv i les primeres del xv. Aquests models escultòrics, que en molts casos estaven lligats a les corts de París i Borgonya, podien haver estat importats a Catalunya al llarg de les primeres dècades del segle Xv, com va succeir amb els models pictòrics ${ }^{75}$.

És possible que l'escultura tingués la precedència en la creació del tipus de la Verge amb el Nen escrivint i potser també en el de la Verge amb el Nen i el llibre. A Claus de Werve i el seu cercle s'atribueixen dues imatges, la Verge del Fundador de la col-legiata de Saint-Hippolyte de Poligny ${ }^{76}$, on el Nen porta el llibre tancat, i una segona escultura on l'Infant obre el còdex sense gaire cura. Aquesta imatge on el Nen no només llegeix o assenyala, sinó que també passa les pàgines tot rebregant-les, en un gest ple d'espontaneitat, farà fortuna dins del nou realisme flamenc. Entre els diversos exemples conservats destaca la Madonna Durán, del Museo del Prado (Poo2722), pintada per Rogier van der Weyden i versionada per artistes com el Mestre del fullatge brodat ${ }^{77} \mathrm{o}$ l'aragonès Bernardo de Aras, en aquest cas a la taula central de retaule de la Mare de Déu, de Pompién, Osca (contractat el $\left.{ }^{1} 46 \mathrm{I}\right)^{78}$. En el cas del Nen que rebrega les pàgines com volent arribar a un punt concret del manuscrit, crec que sí que podem pensar en una al-lusió a la superació de l'Antiga Llei gràcies a la seva vinguda, com suggeria Laguna-Chevillotte. És aquesta interpretació la que s'escauria millor, segons la meva opinió, a una altra obra de Rogier van der Weyden conservada fragmentàriament: una taula amb la Mare de Déu amb el Nen i sis sants. Els fragments localitzats en diversos museus, així com un dibuix del Mestre de Koberger Rundblätter (Museu Nacional d'Estocolm) permeten reconstruir versemblantment l'obra i fer-ne una anàlisi iconogràfica ${ }^{79}$. El Nen se situa a la falda de Maria, asseguda entre sant Joan Baptista i sant Joan Evangelista. Una mica més enretirats assisteixen a l'escena uns altres sants. El detall que ens n'interessa ara afecta la gestualitat del grup central: sant Joan Baptista està dempeus i mostra el llibre obert a l'espectador, mentre que sant Joan Evangelista s'agenolla per permetre que el Nen escrigui en el llibre que ell sosté. El Baptista es mostra, així, com el precursor de Crist, atès que anticipa els evangelis que l'Infant sembla en curs d'escriure. En aquest cas, la sacra conversazione i la presència del donant, que ens obliguen a pensar en la súplica a la divinitat $i$ la presència de mitjancers que advoquen a favor d'aquesta súplica, se suma a la representació d'aquests dos moments de l'Aliança de Déu amb els Homes, abans i després de la vinguda de Crist.

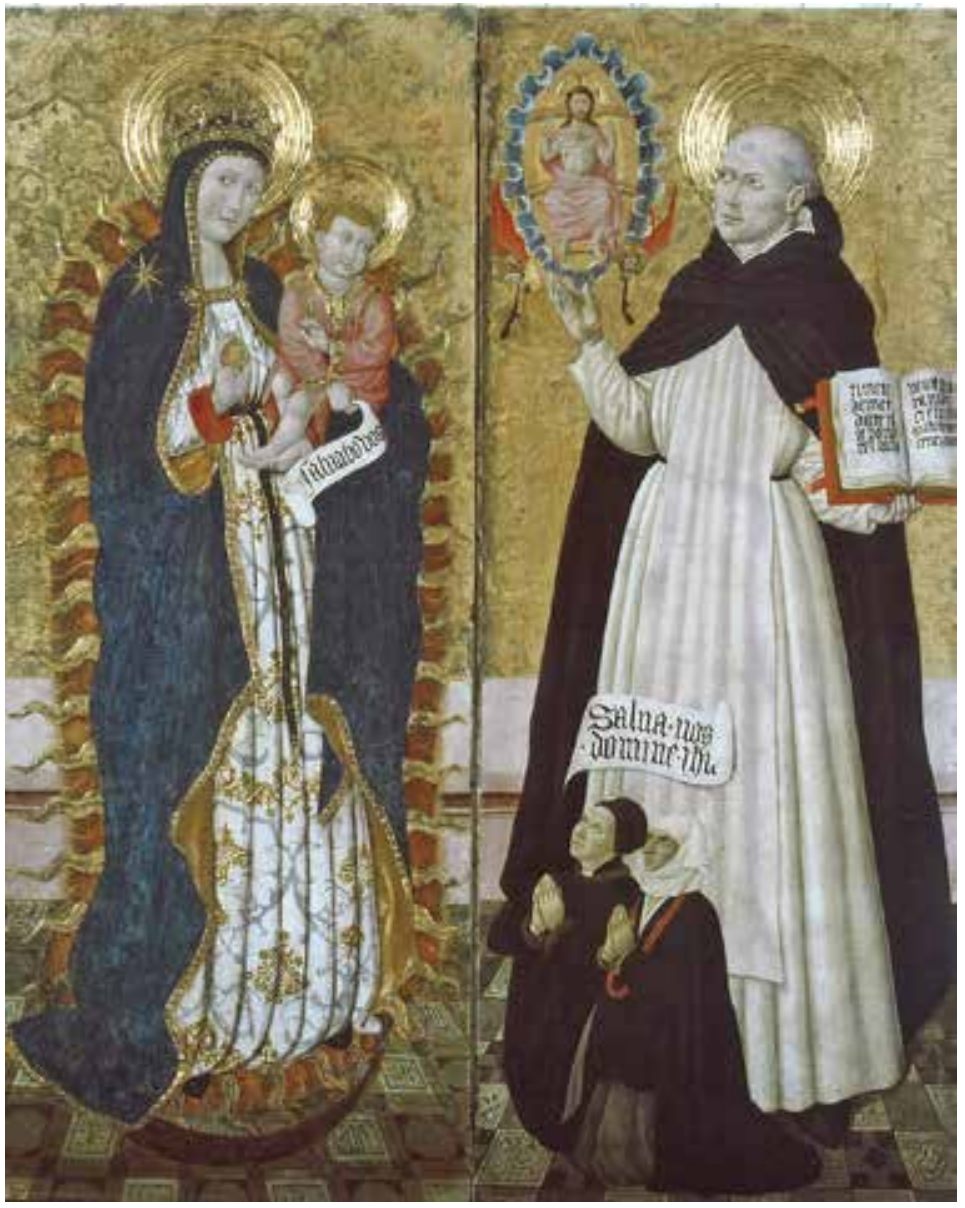

Figura 7.

Pere Garcia de Benavarri, Mare de Déu amb el Nen i sant Vicenç Ferrer, compartiments centrals d'un retaule. Barcelona, MNAC (inv. 114749-000).

\section{Judici i sentència}

Tal com he avançat, al tercer exemple que examinarem, el Nen no escriu i tampoc no llegeix, però estableix una animada conversa amb els donants a partir d'un model iconogràfic que, com intentaré fer palès, deriva d'altres exemples on l'infant sí que es dedica a aquestes activitats. Es tracta de dos compartiments del Retaule de la Mare de Déu i sant Vicenç Ferrer, obra de Pere Garcia de Benavarri ${ }^{80}$ (figura 7). Hem conservat aquest conjunt incomplet i dispers: al MNAC (inv. I I 4749-000) s'hi exposa la taula de la Mare de Déu i sant Vicenç Ferrer ${ }^{81}$, que degué formar part del cos superior del retaule, i al Musée des Arts Décoratifs de París (inv. PEı 27) hi ha una taula de dimensions menors amb la professió de sant Vicenç a l'orde dominicà ${ }^{82}$, que molt probablement va pertànyer a la predellla, atès l'assemblatge horitzontal de les posts que la integren. Una antiga cromolitografia ens informa de l'existència d'un tercer compartiment, amb sant Vicenç pacificant les bandositats de dues famílies valencianes, els Vilaregut i els Centelles ${ }^{83}$, 


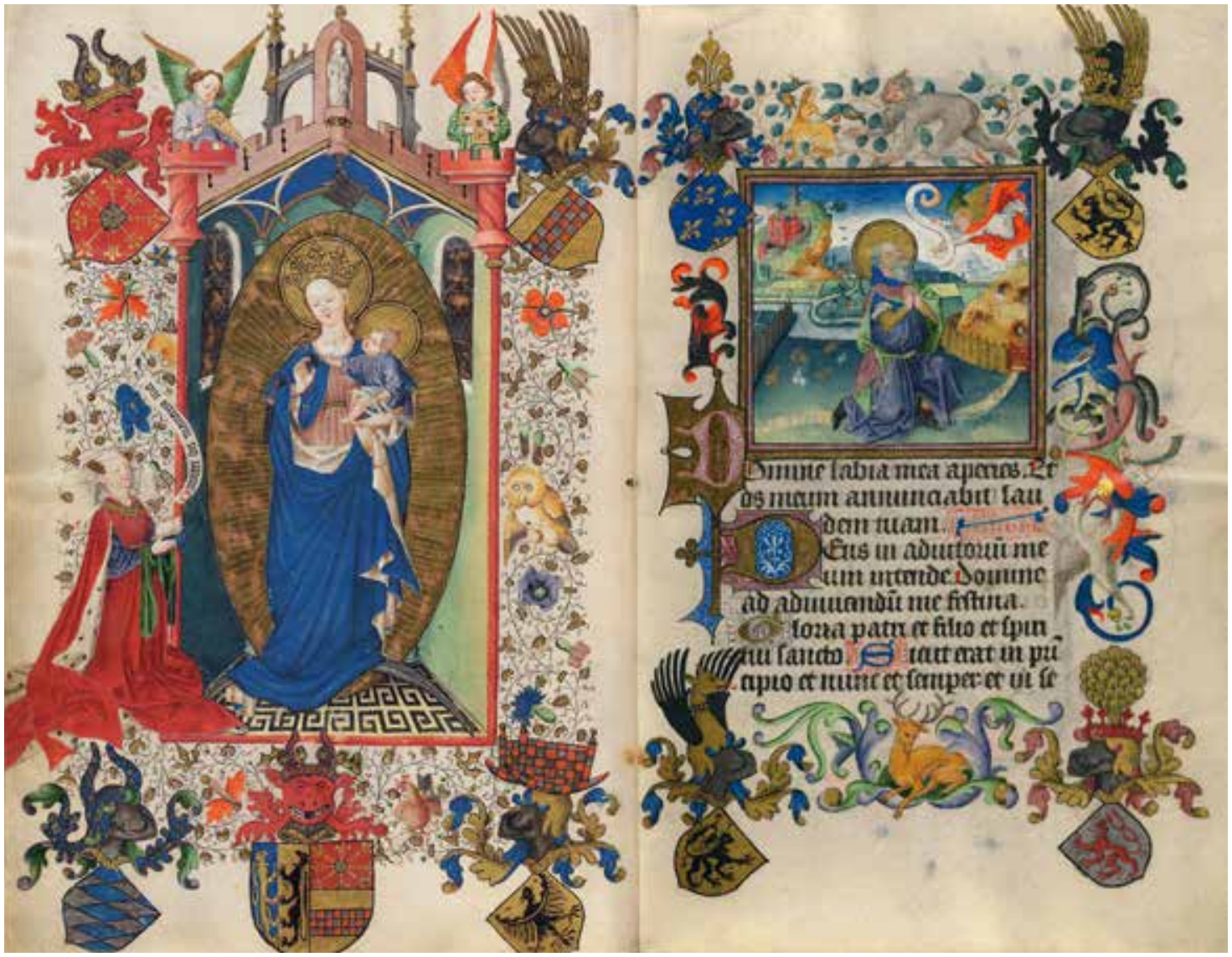

Figura 8 .

Caterina de Clèves en pregària davant de la Mare de Déu amb el Nen que escriu, miniatura del Llibre d’hores de Caterina de Clèves. Nova York, The Morgan Library and Museum, m. 917/945, foli 1v.

que s'hauria integrat també al bancal ${ }^{84}$. Alberto Velasco suggereix a la seva tesi doctoral que el tercer compartiment, que caldria situar a l'esquerra de la Mare de Déu i sant Vicenç Ferrer per completar el conjunt, podia haver estat una taula amb sant Antoni Abat, llavors en venda a la galeria Mercè Ros, de Madrid ${ }^{85}$, i més tard venuda a la casa de subhastes La Suite, de Barcelona ${ }^{86}$.

Les peces ressenyades permeten definir un tipus de moble d'altar de dimensions mitjanes que té força èxit en els contextos valencià $i$ aragonès al llarg del segle xv. De fet, coneixem exemples molt propers en estructura $\mathrm{i}$ iconografia sorgits del propi obrador de Pere Garcia de Benavarri. El Retaule de sant Ponç, la Mare de Déu i sant Macari, conservat al Museu de Lleida: Diocesà i Comarcal, s'inspira sens dubte en el Retaule de la Mare de Déu $i$ sant Vicenç, tant pel que fa a la seva estructura com a la representació concreta de la Verge amb el Nen. La inclusió dels donants a la taula amb sant Vicenç dona lloc a una composició molt coherent, on sembla dificultós l'afegit d'un tercer sant, que quedaria una mica al marge d'aquest grup. No seria, però, un cas únic: al Retaule de sant Martí, sant Nicolan i sant Bartomen, del Grup de Morata, el donant ocupa el compartiment de sant Nicolau, a la taula lateral esquerra. Cal remarcar, finalment, que la Mare de Déu i sant Vicenç van ocupar, originàriament, una mateixa taula, tallada amb posterioritat. Així ho indiquen les unions de les posts i de les restes d'endrapat. També el Retaule de sant Ponç, la Mare de Déu i sant Macari estava format per una única taula integrada per diverses posts, i el mateix succeeix al cos superior del Retaule de la Mare de Déu, sant Fabià i sant Sebastià, també al Museu de Lleida i atribuïble al taller de Pere Garcia. Devia tractar-se, per tant, d'una estructura habitual en el cas de retaules de dimensions mitjanes amb diversos titulars, com ja vaig suggerir a la meva tesi doctoral ${ }^{87}$.

Pel que fa a l'encaix de la taula de sant Antoni Abat proposada per Velasco per completar el conjunt, cal fer constar que l'estil s'adiu amb el de les taules del MNAC i el museu parisenc. També la seva iconografia resulta molt apropia$\mathrm{da}$, atès que, com veurem tot seguit, l'obra fou encarregada per a la capella funerària d'un carnisser cerverí, n’Antoni Cabeça. El sant porta, a més, un llibre obert on es llegeix: «[...] Intercesio nos quesumus domine beati Anthoni Abattie», que redundaria en el missatge escatològic 
i salvífic de la resta de la composició. Caldria, això sí, i és un aspecte que no he pogut examinar, veure com podria encaixar aquesta taula, retallada per la seva part baixa, amb les del MNAC, que, remarquem, al començament eren una de sola. D'altra banda, hi ha alguns detalls compositius que divergeixen de l'organització dels elements del compartiment amb la Mare de Déu i sant Vicenç Ferrer. Pel que fa al fons de la taula, el sant es disposa, com és molt habitual, davant d'un mur i un fons daurat punxonat, com si es tractés d'una peça de teixit brocat. Així succeeix també a la taula del MNAC, però el mur de sant Antoni abat s'aixeca fins a la cintura del sant, mentre que el situat darrere de Maria i sant Vicenç Ferrer queda, aproximadament, a l'alçada dels genolls. En posar juntes les tres taules la dissimilitud és òbvia. És cert que pot tractar-se d'una «disfunció», d'un error fruit potser de la distribució de les tasques al si del taller, i que això no en descarta del tot la pertinença al conjunt, però cal, si més no, tenir-ho en compte. Com també cal tenir en compte que el disseny del brocat del fons no és idèntic, malgrat que aquí caldria valorar les repintades $i$ les neteges sofertes per les taules.

Inicialment, l'obra s'havia adscrit, en funció del seu estil, a l'«etapa barcelonina» de Pere Garcia ${ }^{88}$, és a dir, els anys en què l'artista va estar al front del taller del difunt Bernat Martorell, mort el 1452 . Tot $\mathrm{i}$ que els pactes signats amb la vídua de Martorell obligaven Garcia a viure a Barcelona al llarg del període de vigència del contracte, des del gener de 1456 i per cinc anys, sabem que el i 460 tornava a residir a Benavarri, la qual cosa obliga a pensar en un trencament dels pactes. Les aportacions documentals de Llobet Portella del 2003 lligaven encara amb més fermesa el retaule a aquesta etapa. Noves descobertes, efectuades pel mateix autor, corregeixen parcialment les propostes anteriors $\mathrm{i}$ permeten situar amb molta més precisió la factura del retaule, el seu comitent i la destinació original ${ }^{89}$. Sabem, així, que el pintor tornava a residir a Benavarri quan va cobrar aquesta obra, el I460, però que degué pintar-la en un lapse de temps molt proper a la factura del Retaule de santa Clara $i$ santa Caterina, de la catedral de Barcelona, i al Retaule de sant Quirze i santa Julita, de Sant Quirze del Vallès (Museu Diocesà de Barcelona). L'estil encaixa a la perfecció amb aquestes aportacions documentals. El retaule de Cervera és una obra de factura acurada que, com els retaules barcelonins o les taules de la Mare de Déu amb el Nen i àngels (MNAC, o I 58 I 7-000), i els Sant Pere i Sant Antoni abat (Musée Goya de Castres, 97-I-I i 97-I-2), de Bellcaire d'Urgell, ens permet veure el millor Pere Garcia ${ }^{90}$. Els compartiments narratius petits, com ara el de la professió de sant Vicenç, sempre afavoreixen una pintura detallista i primmirada, com succeeix al retaule de dimensions mitjanes dels dos sants màrtirs. D'altra banda, el modelat pàllid, els suaus tocs de llum als cabells i els rostres es retroben a la delicada Santa Bàrbara, del MNAC (015933-000) ${ }^{91}$, o al Sant Miquel, de l'església de Sant Pere de l'Ametlla de Segarra $(\mathrm{MEV} 869)^{92}$.

El que m'interessa ara és subratllar la similitud de la composició de la taula del MNAC amb diverses pintures, gravats i relleus escultòrics que, a més d'una organització molt propera dels elements, inclouen el motiu de l'escriptura. A la meva tesi doctoral ja vaig comentar, tot i que amb relativa brevetat, aquest aspecte, al-ludint a la connexió entre la taula cerverina i la miniatura inicial d'un manuscrit destacat per la seva factura i la seva riquesa iconogràfica, el Llibre d'bores de Caterina de Clèves ${ }^{93}$ (figura 8). A les línies que segueixen intentaré ampliar aquesta qüestió. Cal, en primer lloc, parar atenció a la composició del retaule, tot tenint en compte que es tracta d'un moble destinat a un espai funerari.

La Mare de Déu presideix el conjunt, amb el Nen als braços, sostenint amb la mà dreta el que sembla una pera, mentre sobre el braç esquerre seu el Nen, de nou un petit infant, més que no pas un nadó. La Verge vesteix, com la Maria de la taula de Martorell, una túnica blanca brocada d'or i es cobreix del cap fins als peus amb un mantell blau sobre el qual destaquen el daurat de la corona i un estel que brilla damunt de l'espatlla dreta. Es tracta de referències òbvies a Maria com a contrafigura d'Eva i al seu destí com a Reina dels Cels, que se sumen a les referències a la dona apocalíptica. Tota la figura de Maria apareix orlada pels rajos del sol i els seus peus es disposen sobre el creixent de lluna. Ja hem vist que alguns dels atributs apocalíptics acompanyaven la Verge amb el Nen de Martorell. Com en aquell cas, aquesta iconografia reforça el seu caràcter de mitjancera. Paulino Rodríguez $\mathrm{Ba}$ rral citava sant Bernat de Claravall, qui veu: «en la mujer envuelta en el sol a la Virgen, pero para él el sol es la imagen de la infinita misericordia de María, clemente y compasiva, mientras que la luna que pisotea simboliza el Mal...» ${ }^{94}$. No crec, per contra, que la lluna als peus de la Verge sigui «una possible al-lusió al seu influx sobre la fertilitat femenina», com proposà Alberto Velasco ${ }^{95}$.

Maria dirigeix la seva mirada cap a nosaltres, cap a l'espectador, però el Nen, en canvi, mira els donants: Antoni Cabeça i la seva esposa, agenollats als peus de sant Vicenç Ferrer. Aquest darrer, ben conegut per la seva prèdica de signe apocalíptic, assenyala amb una mà la representació del Crist del Judici Final, mentre sosté amb l'altra un llibre obert on es pot llegir el text de 


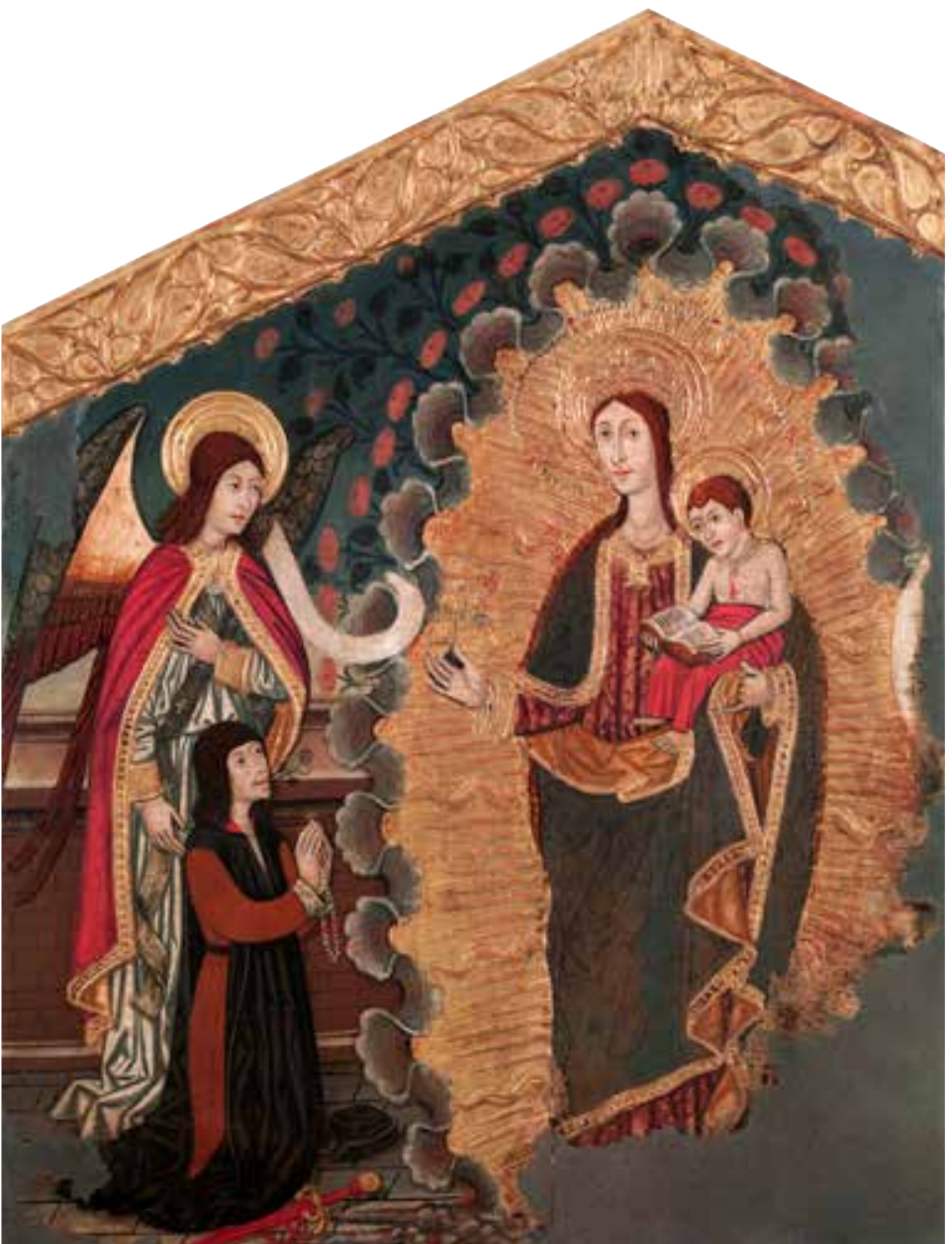

Figura 9.

Mestre de Viella (Bartomeu Garcia?), Aparició de la Mare de Déu del Roser al cavaller de Colònia. Barcelona, MNAC (inv. 015904-000).

l'Apocalipsi «Timete deum et date ille honorem quia veniet hora iudicius eius» ${ }^{96}$, a més del prec: «Santus Vicencius ora». El joc de mirades dels protagonistes del retaule és molt rellevant. Sant Vicenç Ferrer no s'adreça als donants, sinó que aixeca els ulls vers la visió apocalíptica: Crist apareix vestit amb un mantell rosat i ostenta les nafres de la Passió. Seu sobre l'arc de Sant Martí, com és molt habitual en les representacions de caire narratiu del Judici, i s'aureola amb una resplendor daurada $\mathrm{i}$ una màndorla en forma de núvols arrissats que al·ludeixen a l'obertura dels cels. Dos àngels amb trompetes anuncien la fi dels temps i la imminència del Judici Final. Concorrerien, doncs, dues visions de la segona persona de la Trinitat en el mateix context, tot i que és cert que aquest Crist del Judici Final funciona, fins a cert punt, com a «atribut» del sant. Però no només: mentre Crist mostra el seu sacrifici, que el qualifica alhora com a Redemptor i Jutge, el Jesús nen, molt més amable, respon des dels braços de Maria al prec dels dos orants mitjançant el filacteri que sosté a la seva mà.
Els donants preguen: «Salva·nos·domine·ihu», i Jesús contesta: «Salvabo vos», generant així un diàleg molt similar als dels llibres de Pere de Luxemburg o Maria de Berry. Recordem que del taller de Pere Garcia sorgí una taula molt similar a aquesta, integrada al Retaule de sant Ponç, la Mare de Déu i sant Vicenç (MLDC). Allà Maria es presenta també dempeus, amb un fruit a la mà i el Nen sobre el braç. L'Infant desplega un filacteri on es pot llegir: «qui venit ad me non ejiciam fores» (Joan 6,37). Malgrat les similituds compositives el missatge és força diferent: en no comparèixer els donants, les paraules del Nen prenen un caire genèric, adreçades a tota la humanitat, i desapareixen també uns altres elements escatològics, com ara els atributs apocalíptics que revesteixen la Verge a la taula del MNAC. Podem citar una altra pintura derivada del mestratge de Pere Garcia, l'Aparició de la Mare de Déu del Roser al cavaller de Colònia (MNAC, inv. o I 5904-000), on el Nen apareix en braços de Maria sostenint un llibre obert amb escriptura figurada. La Verge està coronada i aureolada amb rajos daurats, tot i que les pèrdues sofertes per la taula impedeixen comprovar si hi apareixia també l'atribut lunar. Un àngel amb un llarg filacteri sense text acompanya el donant, el prec del qual es transmuta en roses que surten dels seus llavis (figura 9).

A la miniatura del Llibre d'bores (figura 8), Caterina de Clèves prega a una Mare de Déu que també s'ha representat dreta, envoltada de sol i amb la lluna als peus, dient «O Mater Dei memento mei», una invocació recurrent, com hem vist, en aquest tipus d'imatges, tot $\mathrm{i}$ que fins ara l'hem trobat en exemples sedents. Aquesta frase, que es pot incloure, per exemple, al final de la recitació de l'Ave Maria, li serveix a Caterina per demanar la intercessió de Maria, però no és ella qui respon. És Jesús qui contesta al prec, tot $\mathrm{i}$ que, a diferència del que succeeix a la taula del MNAC i del que hem vist al llibre de pregàries de Pere de Luxembourg o al compendi de Maria de Berry, el moment ha quedat detingut en l'instant en què l'Infant escriu sobre un filacteri, de manera que no sabem si l'oració de Caterina i la intercessió de la Verge obtindran el resultat esperat. La taula del MNAC i la miniatura comparteixen la iconografia i la intenció de la imatge: la sol-licitud a la Verge perquè intervingui en la recerca de la misericòrdia divina, en el benentès que finalment serà Déu - aquest infant que escriu o que ja ha escrit al seu filacteri- qui salvarà o condemnarà l'ànima que s'adreça a la seva mare. Però, a més, aquest significat es vehicula a través d'una forma extraordinàriament propera, si no en el seu estil, sí en la seva composició, en l'ordenació dels elements que la integren. 


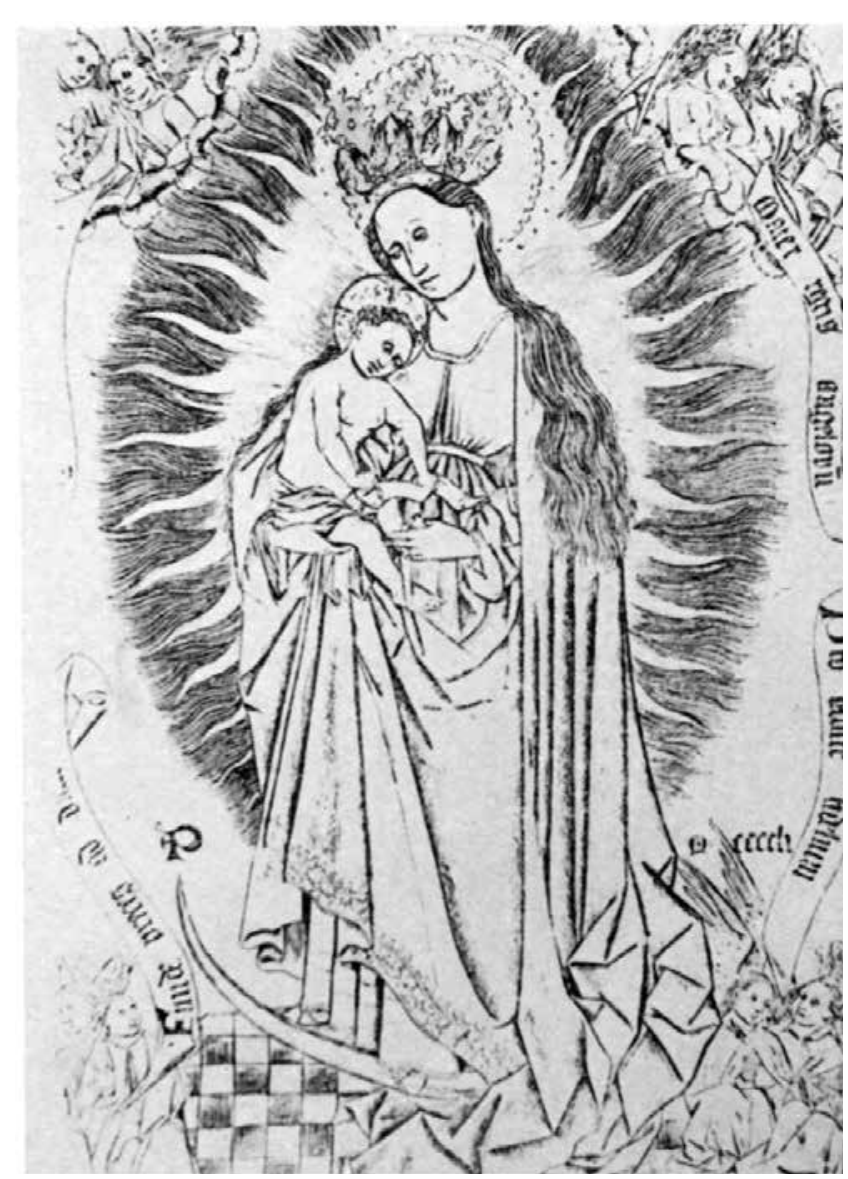

Figura 10.

Mestre P, Mare de Déu apocalíptica amb el Nen que escriu, gravat, 1451.

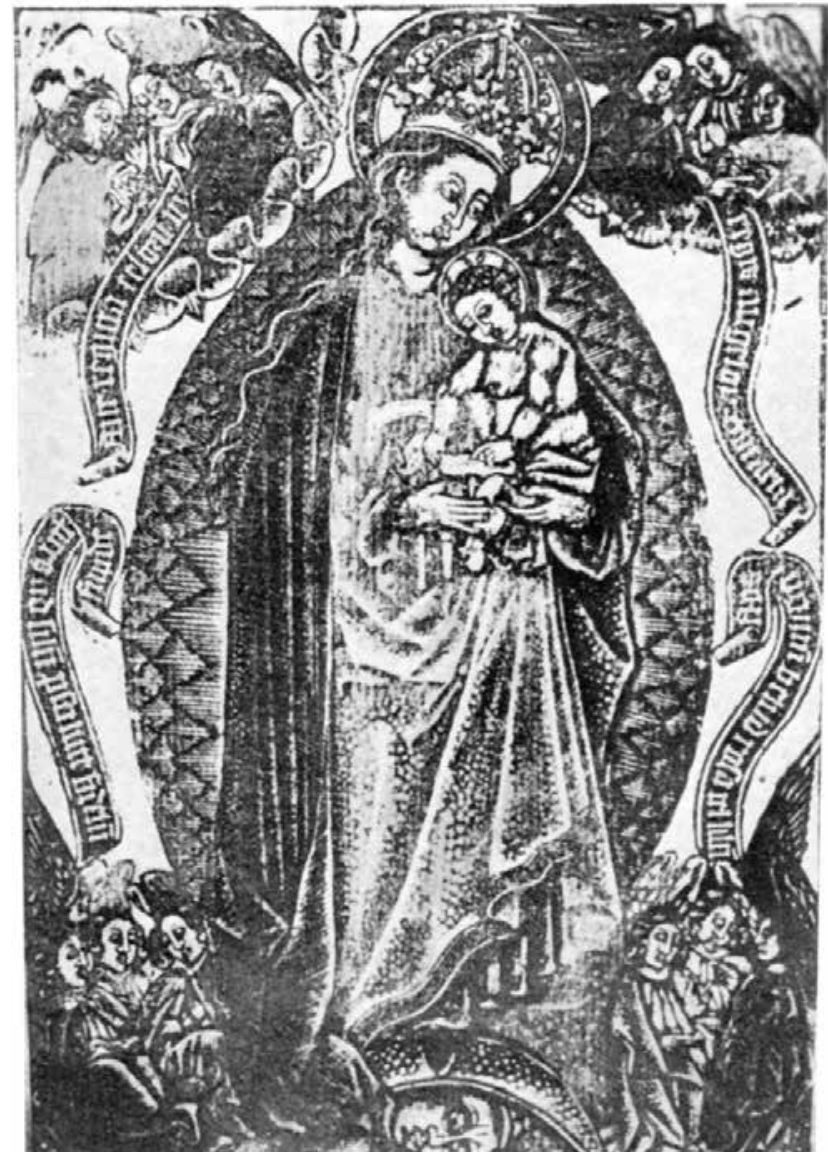

Figura 11.

Mare de Déu apocalíptica amb el Nen que escriu, gravat, cap a 1450-1460.
Hi ha uns altres exemples on es conjuga la Mare de Déu dempeus, elements apocalíptics i el Nen escrivint. Vetter publica una taula d'àmbit neerlandès i datable, segons la seva opinió, al voltant de mitjans del segle Xv que va pertànyer a la col-lecció del comte de Wenyss (Escòcia) ${ }^{97}$. L'articulació dels elements i fins i tot la manera com la túnica de Maria cau sobre el creixent de lluna presenta força similituds amb la miniatura del Llibre d'hores. Parkhurst, d'altra banda, citava dos exemples del camp escultòric, un dels quals també és present en el context de la retaulística, inclòs en un dels altars de la catedral de Lübeck, de cap a I460, i l'altre a l'església de Notre-Dame de Maastrich, ja de ben entrat el segle XvI ${ }^{98}$.

No podem oblidar que la Verge representada com a Mulier amicta sole fou un tema recurrent en els gravats. Es troba de manera molt habitual a les xilografies, primer, i més tard a les calcografies d'àmbit alemany $i$ centreeuropeu a partir dels voltants de $1420 \mathrm{i}$ tot al llarg dels segles $\mathrm{xv}$ i xvI, amb formulacions força variables que de vegades integraven advocacions particulars, com ara la Mare de Déu del Roser i altres. Parkhurst inclou al seu ampli estudi dos gravats amb uns ingredients molt semblants als de la miniatura del llibre de Caterina de Clèves i la taula cerverina. N'hi ha un que està datat el I 45 I i que s'atribueix al Mestre P (figura Io). Sembla que podria estar basat en un prototipus del Mestre de les Cartes de Joc. L'altre, de menys qualitat, deriva probablement del mateix model $i$ es pot datar cap al 1450-146099 (figura I I). En tots dos casos la Mare de Déu es presenta dempeus sobre un creixent de lluna, aureolada de rajos solars, coronada i amb l'Infant als braços. El Nen desplega un filacteri on escriu i al voltant s'hi disposen àngels que ostenten també filacteris amb inscripcions. Al gravat atribuït al Mestre P s'hi poden llegir les frases «Mater regis angelorum», «funde preces ad dominum» $i$ «pro salute fidelium», extretes d'una de les antífones marianes de la missa, cantada en el moment de la comunió ${ }^{100}$. Els textos insisteixen, doncs, en la capacitat intercessora de Maria, igual com ho fan les pregàries que li adrecen els donants en alguns dels llibres il-luminats. Una recerca més aprofundida podria proporcionar uns altres exemples que ens donessin, potser, idea de com aquesta iconografia s'expandeix i penetra en espais com ara el català i l'aragonès, pels quals es va moure Pere Garcia. 
Voldria remarcar, d'altra banda, que el filacteri és un element essencial d'aquestes composicions en mans del Nen, com a suport de la seva escriptura i, doncs, com a vehicle de comunicació amb el donant. Pren, a més, un paper destacat en mans de personatges secundaris en algunes de les escenes que mostren Crist escrivint. És el cas dels gravats que acabo de citar, però també dels àngels que acompanyen la Mare de Déu i el Nen en un llibre d'hores de la biblioteca municipal de Carpentras o dels que flanquegen Maria en una taula del Louvre, que presenta la particularitat, a més, que Crist jeu sobre el llibre com si s'hagués adormit ${ }^{101}$. També despleguen llargs filacteris els quatre àngels d'un altre llibre d'hores atribuït al Pseudo-Jacquemart, que acompanyen Maria entronitzada amb el Nen escrivint ${ }^{102}$. L'ús dels filacteris amb inscripcions reforça el context de conversa sagrada, de comunicació amb el donant i d'intercessió al seu favor. Una altra escena del Llibre d'hores de Caterina de Clèves - on els filacteris tenen una presència molt destacada en moltes de les escenes - ens il-lustra sobre aquest particular. Es tracta de la miniatura que encapçala la missa de dissabte de la Verge, dedicada al tema conegut com a «doble intercessió» ${ }^{103}$. Crist penja a la creu i al seu costat s'agenolla la Mare de Déu, que mostra un dels seus pits. Al costat oposat de la creu s'agenolla Caterina, acompanyada per un sant protector, $\mathrm{i}$ al marge superior esquerre de la composició apareix Déu Pare. El llibre obert sobre un tamboret a primer terme sembla indicar que tota l'escena és fruit de la meditació i l'oració de la pròpia donant, però l'aspecte més destacat és la conversa que s'estableix. Caterina prega a la Mare de Déu, a qui es dirigeix amb el títol de «dei genitrix». Maria, al seu torn, dirigeix la seva súplica a Crist, qui exerceix també com a intercessor i aixeca el cap per transmetre-la a Déu Pare, constituït com a únic jutge. Aquest darrer contesta que l'oració és escoltada. Amb aquesta afirmació respon a la demanda efectuada per Caterina a la miniatura inicial del còdex, que, recordem, havia quedat en suspens.

En resum, la imatge de la Mare de Déu amb el Nen que escriu o llegeix és polièdrica i susceptible de vehicular continguts diversos que cal, per tant, situar en el seu context precís. Sorgida potser en un ambient de reivindicació eclesial, és plausible que almenys algunes de les escultures monumentals d'aquest tema plantegessin la figura de Maria com a encarnació simbòlica de l'Església, sostenint un petit Crist ocupat a redactar la nova aliança amb els homes, com defensà Laguna-Chevillotte. Més enllà, però, d'aquesta presència lligada a l'arquitectura, la Mare de Déu amb el Nen escrivint s'insereix en contextos on adquireixen un gran protagonisme el donant $\mathrm{i}$ la seva pregària i on tot sovint concorren també elements apocalíptics que afegeixen un contingut escatològic a l'escena. La figuració de Crist com a infant no amaga que es tracta del nostre Jutge, qui tindrà la darrera paraula en el moment del Judici Final, però alhora posa l'accent en l'Encarnació i, doncs, en el paper de Maria com a mare $i$ en la seva capacitat d'intercessora. 
1. Entre els nombrosos estudis dedicats a la construcció teològica $i$ artística de la figura de la Verge al llarg de l'edat mitjana destaquen Marina Warner (1976), Alone of all her sex: The Myth and the Cult of the Virgin Mary, Nova York, Random House, i Miri Rubin (2009), Mother of God: A History of the Virgin Mary, Londres, Penguin Books. Podeu trobar una visió general de la qüestió artística a Jean Wirth (2008), L'image à l'époque gothique (1140-1280), París, Cerf.

2. Rocío Sánchez Ameijeiras (2009), «Crisis ¿qué crisis?: Sobre la escultura castellana de la primera mitad del siglo XIV", a Rosa AlcoY (ed.), El Trecento en obres: Art de Catalunya $i$ art d'Europa al segle XIV, Barcelona, Universitat de Barcelona, p. 243-272; Jeffrey F. Hamburguer (1997), Nuns as artists: The Visual Culture of a Medieval Convent, Berkeley, Los Ángeles, University of California Press; Ídem (1998), The Visual and the Visionary: Art and Female spirituality in Late Medieval Germany, Nova York, Zone Books, i Mary Dzon (2017), The quest for the Christ child in the latter middle ages, Filadelfia, University of Pennsylvania Press.

3. C. Walker Bynum (1982), Jesus as Mother: Studies in the Spirituality of the High Middle Ages, Berkeley, Los Ángeles, Londres, UCLA.

4. Entre les aportacions recents a aquesta qüestió pel que fa a l'àmbit català, vegeu Rafael CoRnUdella, Guadaira Macías i Cèsar Favì (2012), Catalunya 1400: El Gòtic Internacional, catàleg d'exposició, Barcelona, MNAC, especialment p. 15-21. També Rosa Terés (dir.) (2016), Catalunya i l'Europa septentrional a l'entorn del 1400: Circulació de mestres, obres i models artístics, Barcelona, Universitat de Barcelona, IRCVM, Viella. És impossible, en un estudi com el present, referenciar l'extensa bibliografia sobre el gòtic internacional o reflexionar sobre la incidència, en la seva definició, d'alguns corrents nacionalistes, el procés de construcció de l'espai europeu i altres condicionants sociopolítics. No voldria, però, deixar de citar alguns clàssics, com ara els tres volums que recullen les Leçons professées à l'École du Lowvre (1887-1896), de Louis Courajod, especialment el volum II (Origines de la Renaissance, París, 1901), on ja empra el terme. Un terme que recull i matisa Erwin PANOFSKY a Early Netherlandish painting: Its origins and character, Cambridge
(Massachusetts), Harvard University Press, 1953, encara ara de lectura obligada. També és una fita ineludible l'exposició «Europäische Kunst um 1400», organitzada pel Consell d'Europa el juliol de 1962 al Kunsthistorisches Museum, de Viena. El seu catàleg agrupa importants contribucions, com ara, pel que fa al camp pictòric, les de Charles Sterling (1962), «La peinture en Europe vers 1400", a Vinzenz Oberhammer (ed.), L'art européen vers 1400 , Viena, p. 71-82.

5. Manuel Trens (1947), María: Iconografía de la Virgen en el arte español, Madrid, Plus-Ultra, p. 566-578.

6. Guglielmo Cavallo i Rogier Cartier (dir.) (1998), Historia de la lectura en el mundo occidental, Madrid, Taurus, i Martyn Lyons (2012), Historia de la lectura y la escritura en el mundo occidental, Buenos Aires, Editoras del Calderón.

\section{Séverine Lepape (2013), Les} origines de l'estampe en Europe du nord, 1400-1470, París, Louvre éditions, fig. 26.

\section{J. Wirth (2011), L'image à la} fin du Moyen Âge, París, Cérf, p. 183-191.

9. Vegeu Guadaira MacíAs, «Jaume Ferrer: Taules del Retaule de la Mare de Déu», a Catalunya 1400 ..., op. cit., p. 217-219, i ÍDEM, «Jaume Ferrer i taller/Mestre de la predel-la de la Paeria: Retaule de la Mare de Déu, sant Miquel i sant Jordi", a Catalunya 1400..., op. cit., p. 222-225. No podem deixar d'esmentar, com a dona escriptora però també, i sobretot, com a dona representada escrivint, Christine de Pizan, que tot sovint apareix dedicada a la seva tasca intel-lectual en els manuscrits que recullen la seva obra. És el cas, per exemple, del foli 2 de Le livre de mutation de Fortune, de voltants de 1403 (Biblioteca Reial de Brusel-les, ms. 9508). Sobre el tema de la dona i la cultura literària a l'edat mitjana, vegeu Lesley SMITH (1997), «Scriba femina: Medieval depictions of Women Writing», a Women and the book: Assessing the Visual Evidence, Toronto, University of Toronto Press, p. 21-44. Ja en temps del Renaixement, vegeu Susan Schibanoff (1994), «Botticelli's Madonna del Magnificat: Constructing the Woman Writer in Early Humanist Italy», PMLA, Modern Language Association, 109(2) (març), p. 190-206. Pel que $\mathrm{fa}$ al context hispànic, vegeu
Joaquín YARZA (2002), «La santa que lee», a María Teresa SAURET i Amparo Quiles (coords.), Luchas de género en la historia a través de la imagen: Ponencias y comunicaciones, Málaga, Universidad de Málaga, p. 421-468; Isabel Beceiro (2003), «La relación de las mujeres castellanas con la cultura escrita (siglo XIII-inicios del XVI)», a Antonio Castillo (coord.), Libro y lectura en la Peninsula Ibérica y América, siglos XIII - XVII, Valladolid, Junta de Castilla y León; María Isabel Toro (2005), " "Sic vos non vobis": La imagen de la mujer, vía transmisora de conocimiento en la literatura medieval», a María Carmen Sevillano Sanjosé (ed.), El conocimiento del pasado: Una herramienta para la igualdad, Salamanca, Plaza Universitaria Ediciones, p. 219-240, entre d'altres.

10. A les anomenades Hores de Bedford (British Library, Add, ms. 18850, f. 199v.) la Verge i el Nen seuen en un interior domèstic acompanyats per àngels. La il.lustració de les Hores servades a la British es repeteix de manera pràcticament idèntica en unes Hores de la Biblioteca Nacional de Viena (ms. 1855, f. 202v., Charles P. Parkhurst JR. (1941), «The Madonna of the Writing Christ Child», The Art Bulletin, vol. 23(4), p. 292-306, fig. 24). Malgrat l'absència de donants $i$ altres personatges i l'àmbit quotidià, interpretar aquestes imatges com a «instantànies» de la vida de Jesús em sembla una mica ingenu. Totes dues acompanyen una oració a «Notre-Dame des Quinze Joies», molt habitual als llibres d'hores fets al nord del Loira (segons Victor Leroquais (1927-1943), Les livres d'Heures manuscrits de la Bibliothèque Nationale, París, vol. 2, p. 310), que comença amb els mots «Dulce dame de misericorde, mere de pitie, fontaine de tous biens». Una oració que, en ésser recitada, converteix el lector en el donant sol-licitant d'auxili a la Verge que falta a la imatge $i$, en conseqüència, tenyeix l'acció «quotidiana» del Nen amb significats més complexos, propers als de la «Vierge à la supplique» que analitzarem més endavant. El Llibre d'Hores de René d'Anjou, amb una organització textual similar als dos exemples citats, inclou també les quinze joies, però encapçalades en aquest cas per una miniatura on el Nen ja no escriu. L'artista ha preferit concentrar-se a evocar la intensa afectivitat de la relació entre mare i fill (BnF, ms. Lat. 1156 A, foli 92r.).

11. Mary McDevitt (2012), ""The ink of our mortality": The late-medieval image of the Writing 
Christ Child», a Mary Dzon i Theresa M. Kenney (ed.), The Christ Child in Medieval Culture: Alpha est et O!, Toronto, University of Toronto Press, p. 242. Per trobar una anàlisi de la qüestió en clau teològica, vegeu el capítol «La naturaleza del conocimiento según santo Tomás de Aquino", a Ignacio María Manresa (2018), La exégesi en el Espíritu según Santo Tomás de Aquino, Toledo, Instituto Teológico San Ildefonso.

12. Ms. Egerton 2045, f. 216v. Vegeu M. McDeviTT, «"The ink of our mortality”...», op. cit., p. 243.

13. M. Trens, María: Iconografía..., op. cit., fig. 337, p. 573.

14. Resulta interessant constatar el nombre elevat d'imatges de la Mare de Déu amb el Nen llegint o escrivint atribuïbles a Pinturicchio i el seu cercle immediat: la Mare de Déu $i$ el Nen acompanyats per sant Jeroni, a la Gemäldegalerie de Berlín (Ident. Nr. 1481); una taula al Philadelphia Museum of Art (inv. 1336) i una més al North Carolina Museum of Art de Raleigh (GL.60.17.35), entre d'altres.

15. Sobre la disputa del Nen amb els savis del Temple i el seu vincle amb altres escenes, com ara la disputa de sant Esteve amb els jueus, vegeu, per exemple: Rosa Alcoy (1989), «El retaule gòtic de Castellar del Vallès: Sant Esteve i els jueus», Plaça Vella, 26, p. 45-91, especialment p. 62-76. Per consultar la complexa qüestió de l'autoria del retaule d'Ejea, vegeu G. MACÍAs (2013), La pintura aragonesa de la segona meitat del segle $X V$ relacionada amb l'escola catalana: Dues vies creatives a examen, tesi doctoral, Barcelona, Universitat de Barcelona, 2 vols., 1, p. 197-200.

16. Ch. P. Parkhurst JR., «The Madonna of...», op. cit. El mateix autor cita i ressenya unes altres aportacions anteriors al tema, molt més limitades, que ara no analitzaré.

\section{Ibídem, p. 296.}

18. William WixOM (1970), «An Enthroned Madonna with the Writing Christ Child», Bulletin of the Cleveland Museum of Art, 57, p. 285-231. Vegeu també, sobre aquesta obra, Stephen N. Fliegel (2004), «Vierge en majesté avec l'Enfant Jésus écrivant», a L'Art à la cour de Bourgogne: Le mécénat de Philippe le Hardi et de Jean sans Peur, 1364-1419, París, RMN, cat. 131 , p. 338-339, on l'autor afirma que aquesta $i$ altres peces del voltant de 1400 del mateix ambient cortesà francés i borgonyó fan referència al rol d'educadora de la Verge $i$ al futur rol de mestre del Crist adult, aspectes que, com he exposat, cal matisar cas per cas.

19. William H. Forsyth (1986), «A Fifteenth-Century Virgin and Child Attributed to Claux de Werve», Metropolitan Museum Journal, 21, p. 41-63. Poligny fou el centre administratiu del comtat de Borgonya a inicis del segle Xv, i el conjunt d'escultura provinent dels seus edificis religiosos segueix en importància el de la cartoixa de Champmol.

20. «Abans dels segles, des del principi, ell m'ha creat», segons la traducció catalana de la Bíblia de Montserrat, 1992.

21. Vegeu Rafael García MahíQUES (1996), «Perfiles iconogràficos de la Mujer del Apocalipsis como símbolo mariano (y II)», Ars Longa, 7-8, p. 177-184, esp. p. 177; Gerardo Вото (2002-2003), «Cenit y eclipse de la mujer apocalíptica: Los atributos astrales en la iconografía mariana de la baja edad media", Lambard: Estudis d'Art Medieval, 15, p. 53-86. Véronique BOUCHERAT (2004), amb l'eloqüent títol «Claux de Werve: La Vierge éducatrice», a L'Art à la cour de Bourgogne..., cat. 122, p. 328-330, estudia aquesta peça i fa extensible aquesta definició iconogràfica a unes altres obres del mateix artista, com ara una talla de fusta parcialment conservada de l'església de Sant Pere de Château-Chalon, on el Nen fa el gest d'obrir un llibre. Tot i que, com insisteix l'autora, són molt remarcables la naturalitat de la relació entre mare i fill, l'emotivitat de la parella i altres aspectes, no crec que estiguem, com ella afirma, davant d'un «instant de l'intimité familiale de Marie», o, en tot cas, no només.

22. Philippe Verdier (1981), «La Vierge à l'Encrier et à l'Enfant qui Ecrit», Gesta, 20(1), p. 247-256. $\mathrm{Amb}$ anterioritat s'havia ocupat d'aquesta peça Dorothy Miner (1966), «Madonna with Child Writing», Art Nerws, LXIV(10), p. $40-43$ i $60-64$

\section{A L'art à la cour de Bourgog-} ne..., cat. 112, p. 296-297, J. Spicer suggereix que la peça, de gran refinament $i$ amb la presència del que sembla una divisa, potser va ser un encàrrec de la cort borgonyona, tal vegada pintada dins del cercle de Conrad von Soest, atesa la seva semblança amb una taula d'iconografia propera conservada a la Gemäldegalerie de Berlín, còpia d'un original de Von Soest, i també amb l'Anunciació del retaule de Niederwildungen (1403). Seria interessant remarcar-ne també la coincidència iconogràfica i formal, almenys en part, amb algunes miniatures, com ara la del foli $22 \mathrm{v}$. de les Très Riches Heures $d u d u c$ de Berry (Musée Condé, ms. 65), on es representen la Verge i el Nen amb atributs apocalíptics en un tondo, en el context de la Visió d'August.

24. Agnieszka Laguna-ChevilLOTTE (2006), «Le Christ-Verbe: Remarques sur la fortune du thème dans la statuaire mariale de la mouvance royale», La création artistique en France autour de 1400: Actes $d u$ colloque international, Ecole du Louvre, Musée des Beaux-Arts de Dijon, Université de Bourgogne, 9 et 10 juillet 2004, París, Ecole du Louvre, p. 409-430, Rencontres de l'Ecole du Louvre, 19.

25. A. Laguna-Chevillotte (2004), «Atelier tournaisien: Vierge et l'Enfant écrivant», a L'Art à la cour de Bourgogne..., París, Réunion des Musées Nationaux, p. 311-312.

26. Ewal M. VetTer (2006), «Maria mit dem schreibenden Kind», Zeitschrift des Deutschen Vereins fur Kunstwissenschaft, 59-60, p. $111-150$.

27. Bonaventura BASSEGODA I Amigó (1925-1927), a Santa Maria de la Mar, monografia històricoartística, Barcelona, 2 vols., p. 109122 i 178-179, publica la notícia del llibre i les úniques imatges conegudes (la coberta, la portada i el primer full). És ell qui indica que el llibre, un volum de 23 × 30 $\mathrm{cm}$, on es portava la comptabilitat dels censos del Plat de pobres vergonyants de Santa Maria del Mar, es conservava a l'Arxiu de la Junta de l'Obra. M. Trens (María: Iconografía..., op. cit., p. 574, fig. 338) reprodueix la mateixa imatge en parlar de la iconografia de Jesús amb el llibre. També en cita l'exemple P. Verdier, a «La Vierge à l'Encrier...», op. cit., p. 249-250, tot comparant-lo, però sense entrar en detalls, amb el tondo de la Walters Art Gallery, i E.M. VeTTER, «Maria mit dem schreibenden...», op. cit., p. 122, fig. 11.

28. Millard Meiss (1967), French painting in the time of Jean de Berry, Londres, Phaidon, p. 278279, fig. 279 i 280 . Més tard s'hi han referit, entre d'altres, Josefina Planas (2011), «La ilustración del 
libro en la Corona de Aragón», Artigrama, 26, p. 431-477, esp. p. 444-445, fig. 10, i R. CORNUdeLLA, «La il.luminació del llibre a Catalunya al voltant del 1400», a R. Terés (dir.), Catalunya i l'Europa septentrional..., op. cit., p. 96.

29. Aquesta opinió havia estat expressada també per Ch. P. PARKhurst JR., «The Madonna of...», op. cit., p. 300-303.

30. Vegeu M. MeIss, French painting..., op. cit., p. 198 i següents. Per un estat de la qüestió $i$ un recull bibliogràfic recent, vegeu François AvrIL (2004), «Très Belles Heures de Jean de Berry (Heures de Bruxelles)», a Paris 1400: Les arts sous Charles VI, París, Fayard, p. 109-111.

31. A la Vulgata, la traducció llatina emprada a Occident al llarg de tota l'edat mitjana. En les versions actuals corresponen als salms 51 i 70. N'he consultat la versió en línia (<http://catholicbible.online/ vulgate $>$ ).

32. L'alçada de l'estatueta és de $32 \mathrm{~cm}$ i està feta d'ivori d'elefant. Respecte a aquesta qüestió, vegeu Danielle Gaborit-Chopin (1970), «Les ivoires gothiques: A propos d'un article recent», Bulletin Monumental, 128(2), p. 127-133, esp. p. 132.

33. Ch. P. Parkhurst Jr., «The Madonna of...», op. cit., p. 302, n. 58, i M. MeIss, French painting..., op. cit., p. 207.

34. Musée des Beaux-Arts, Chartres, inv. 2886.

35. Meiss i altres identificaven les dues donants com a Maria i una donzella. Més recentment s'identifiquen com la filla i l'esposa del duc a Marie-Thérèse Gousset, «Saint Bonaventura, L'Aiguillon d'amour divin; Henri Suso, L'Horloge de Sapience; Jean Gerson, Sermon prononcé au nom de l'Université devant le roi; Le Chapel des trois fleurs de lys; Règle des preudes femmes", a Paris $1400 \ldots$, op. cit., p. 328.

36. La miniatura inicial del Liber instrumentorum de la catedral de València (Arxiu Capitular de València, ms. 162, foli 11) presenta el tema de la «Vierge à la supplique» amb un ús dels filacteris per establir la conversa entre els donants, la Verge i el Nen que s'apropa, en certa mesura, al llibre de Marie de Berry. Sobre aquest manuscrit, vegeu, per exemple: Josefina Planas (2012), «Un códice inédito conservado en el Archivo Capitular de Zaragoza y su filiación con el gótico internacional de la Corona de Aragón», a María del Carmen LACARra (dir.), La miniatura y el grabado de la Baja Edad Media en los archivos españoles, Saragossa, p. 157-202, esp. p. 193199, fig. 20, i Nuria Ramón (2013), «El estudio del dibujo subyacente en dos manuscritos de la catedral de Valencia», Ars Longa, 22, p. 245-252.

37. M. MeIss, French painting..., op. cit., fig. 655, i George FrECHET (2009), «Le livre de prières du bienhereux Pierre de Luxembourg", Provence historique, 59, p. 445- 458, esp. p. 454.

38. Ch. P. Parkhurst Jr., «The Madonna of...», op. cit., fig. 21, p. 297, el consigna en una col-lecció privada de Brussel-les i no n'identifica el donant. Actualment es conserva al Museo Gulbenkian de Lisboa, ms. L.A. 148. Vegeu James H. Marrow (1995), The hours of Margaret of Cleves, Lisboa, Museau Calouste Gulbenkian.

39. A. Laguna-Chevillotte, «Le Christ-Verbe...», op. cit., p. 423.

40. Beth Williamson (1998), "The Virgin Lactans as Second Eve: Image of Salvatrix», Studies in Iconography, 19, p. 105-138; Ana DOMÍNGUEZ RoDRÍGUEZ (1998), "'Compassio' y 'co-redemptio' en las cantigas de Santa María: Crucifixión y Juicio Final», Archivo Español de Arte, 281, p. 17-35.

41. M. MeIss, French painting..., op. cit., defensa l'existència d'un model perdut, que podia haver estat, fins i tot, de format escultòric, atesa la relativa baixa qualitat de la miniatura catalana $i$ atenent també al fet que el dibuix de la Pierpont presenta alguns elements ostensiblement incomplets o que al-ludeixen a elements presents en l'hipotètic original. Vegeu també Robert W. SCHELlER (1995), Exemplum, Model-Book drawings and the practice of artistic transmission in the Middle Ages, Amsterdam, Amsterdam University Press, p. 225, n. 8, p. 425 .

42. Ch. P. Parkhurst Jr., «The Madonna of...», op. cit., fig. 23, conservat al Kunsthistorisches Museum de Viena. Totes dues accions són força equivalents: en un cas i en l'altre el Nen presta la seva atenció $i$ aprovació a aquell personatge que, en fer professió pública de la fe i reconèixer la divinitat, es converteix, com ha estudiat Rosa Alcoy, en un model ideal per al donant, que tot sovint es representa en un context derivat de l'Epifania. Vegeu Rosa Alcoy (2017), Anticipaciones del Paraíso: El donante y la migración del sentido en el arte del occidente medieval, Vitòria-Gasteiz, Sans Soleil Ediciones. Moltes de les imatges que referencio en aquest article s'inscriuen dins del context de l'«epifania del donant», tal com l'ha estudiat Rosa Alcoy diverses vegades, però, molt especialment, en aquest important i comprensiu estudi.

43. M. MeIss, French painting..., op. cit., p. 207, i B. BASSEgODA I Amigó, Santa Maria de la Mar..., op. cit., p. 178.

44. El gust per la grisalla es desenvolupa a l'època i serà una constant més tard en la pintura del nou realisme nòrdic. Només cal citar algunes de les miniatures del Saltiri de Jean de Berry (BnF, ms. Fr. 13091) o el Missal de la Sainte Chapelle (Bibliothèque Royal de Bèlgica, ms. 9125) per constatar-ho.

45. B. Bassegoda i Amigó, Santa Maria de la Mar..., op. cit., hi va llegir 1301. Ho corregeix Miguel PARdo (1980), «El "Bací dels Pobres Vergonyants", de la Parròquia de Santa Maria del Mar», Estudis històrics $i$ documents dels arxius de protocols, 8, p. 149-164. E.M. VETTER, «Maria mit dem schreibenden...», op. cit., p. 122, fig. 11, indica que es tracta d'un full afegit i data la miniatura cap al 1400 , però no cita la font d'aquestes afirmacions.

46. Judith Berg Sobré (1975), «Le retable de Banyoles et le style internationale», Revue de l'Art, 28, p. 33-39, esp. p. 38. Sobre la circulació d'artistes i models en temps del gòtic internacional, vegeu també R. Cornudella, «Obres i artistes de França i dels Països Baixos a Catalunya al voltant del 1400: Manuscrits il.luminats, pintura sobre fusta, vitralls, brodats i tapissos», a Catalunya $1400 \ldots$, op. cit., p. 24-37.

47. Fora del nostre context, però dins de l'àmbit de la Corona d'Aragó, s'han localitzat uns altres exemples on es pot traçar una relació, més o menys directa, entre la pintura sobre taula, la miniatura francesa i un llibre de models. És el cas de la Resurrecció de Crist del bancal del retaule de sant Jordi del Centenar de la Ploma, conservat al Victoria \& Albert Museum de Londres (inv. 1217-1864), tal com exposa Matilde Miquel (2011) a «El gótico internacional en la ciudad de Valencia: El 
Retablo de san Jorge del Centenar de la Ploma», Goya, 336, p. 206-209 i 213, fig. 15-18.

48. R. W. SCHeller, Exemplum..., op. cit., p. 223, fig. $110 \mathrm{i}$ bibliografía sobre la peça a la pàgina 225 , nota 9 .

49. M. Pardo, «El "Bací dels Pobres...», op. cit., i Maria Piedad Espitia (2006), «Pobreza y caridad en el barrio de la Ribera siglos XIVxv", Ex Novo: Revista d'Història i Humanitats, 3, p. 61-75, esp. p. 69.

50. Habitualment traduït de la manera següent: «Generosa Verge intercedeix per nosaltres davant Déu».

51. Margot E. Fassler i Rebecca A. Baltzer (eds.) (2000), The Divine Office in the Latin Middle Ages: Methodology and Source Studies, Regional Developments, Hagiography, Oxford University Press, p. 469 i 474. S'inclou també en la fórmula «Super Benedictus antiphona: $\mathrm{Hec}$ est regina virginum que genuit regem, velut rosa decora virgo; dei genitrix, per quam reperimus deum et hominem, alma virgo virginum, intercede pro nobis ad dominum», ibídem, p. 476.

52. Procedent del convent de Sant Domènec de València $\mathrm{i}$ ara al Museu de Belles Arts de la ciutat (núm. inv. 240, 242, 243, 2409, 2844 i 4227). Es tracta, a més, d'una Mare de Déu coronada i incorpora el creixent de lluna als peus de reminiscència apocalíptica. La Mare de Déu de la Misericòrdia apareix també amb el Nen en braços i ascendint al cel sobre el creixent de lluna a les Hores de Bedford (British Library, Add., ms. 18850, foli $150 v$.). Vegeu-ne uns altres exemples a Paul Perdrizet (1908), La Vierge de Miséricorde: Étude d'un thème iconographique, París, Bibliothèque des Écoles Françaises d'Athènes et de Rome, 101.

53. R. Cornudella, «Rafael Destorrents: Aplega de Capbreus dels emfiteutes que presten censos als aniversaris comuns del Capítol de la Catedral", a Catalunya 1400..., op. cit., p. 149-150.

54. Rosa Alcoy (1998), a «La pintura gòtica», a Xavier BARRAL I Altet (dir.), Pintura antiga $i$ medieval, Art de Catalunya. Ars Cataloniae, 9, Barcelona, p. $136-329$, p. 274 i 282 , l'atribuí a Joan Antigó, però més recentment vincula l'obra a «un context proper a Martorell», tot subratllant-ne certes peculiaritats a R. AlcoY (2012), «Obres Mestres de la pintura gòtica catalana a Amèrica: Del
Políptic Morgan a la Mare de Déu de Filadèlfia», a R. Alcoy (ed.), Art Fugitiu: Estudis d'art medieval desplaçat, Barcelona, Universitat de Barcelona, p. 139-210, esp. p. 196.

55. Сн. R. Post (1941), A bistory of Spanish painting, Cambridge (Massachusetts), VIII, p. 623-626, fig. 291. Vegeu també José Gudiol RiCART (1959), Bernardo Martorell, Madrid, CSIC.

56. La construcció de la capella entre 1432 i 1434 forneix una dada de referència, però, tal com s'ha defensat en estudis anteriors, l'encàrrec del retaule podia haver antecedit la finalització de l'obra arquitectònica. Vegeu al respecte G. Macías i R. Cornudella (2011-2012), «Bernat Martorell i la llegenda de sant Jordi: Del retaule als brodats», Locus Amoenus, 11, p. 19-53, i íDEM (2015), «El Retaule de sant Jordi de Bernat Martorell», a Marià CARbonell, El Palau de la Generalitat de Catalunya: Art $i$ arquitectura, Barcelona, Generalitat de Catalunya, p. 208-228.

57. Сн. R. Post, $A$ bistory of Spanish..., op. cit., VIII, p. 623-626, fig. 291, i Mary GrIzZARD (1982), «An identification of Martorell's commission for the Aragoneses Corts", The Art Bulletin, 64(2), p. 311-314. A G. Macías i R. Cornudella, «El Retaule de sant Jordi...», op. cit., p. 212-214, aportem nova documentació que permet descartar que la peça fos part de l'encàrrec dels diputats del General de Catalunya per a l'església de Sant Joan de Montsó. Ja hem examinat i descartat també, en les publicacions citades en aquesta nota i l'anterior, la proposta que fa Agustí Duran i Sanpere (1975), Barcelona i la seva història (3): L'art i la cultura, Barcelona, Curial, p. 100-101.

58. Claudie Ressort (2000), Musée du Louvre: Le tableau du mois, n. 1-50, 1993-98, París, p. 175-178; Santiago Alcolea Blanch (2007), «El Retaule de sant Jordi de Bernat Martorell a París, Xicago i Filadèlfia», a Josep Bracons i Jesús Mestre (eds.), Art català al món, Barcelona, Edicions 62, p. 72-75.

59. Sobre la iconografia de la Mare de Déu de la Humilitat, vegeu l'article ja clàssic de Millard Meiss (1936), «The Madonna of Humility», The Art Bulletin, 18(4), p. 435 465. Tot i que no falten els exemples on la Verge apareix en un àmbit celestial o natural, el més habitual és trobar-la asseguda sobre un coixí, en un interior de tipus domèstic més o menys caracteritzat.
60. Vegeu, per exemple, Marie Louise THEREL (1984), Le triomphe de la Vierge-Église: A l'origine du portail occidental de Notre

Dame de Senlis: sources historiques, littéraires et iconographiques, París, CNRS.

61. G. Macías i R. Cornudella, «Bernat Martorell i la llegenda...», op. cit.

62. La pintura de Martorell presenta també coincidències compositives i significatives amb una taula cimera de retaule atribuida al Mestre d'All, provinent de Santa Eulàlia d'Encamp i conservada al MNAC (inv. 15793), estudiada per Cèsar Favà (2014), «De pintura gòtica als Pirineus: El Mestre d'All i els seus vestigis andorrans", a Marta Planas, Benvingudes a casa vostra!: Les obres d'art patrimonials fora d'Andorra, Govern Andorrà, p. 70-90, esp. p. 75-79. En aquest cas, però, el Nen desplega un filacteri amb notació musical i apareix envoltat d'àngels músics, la qual cosa en matisa notablement el significat, que s'allunya de les connotacions «judicials» per insistir en la glòria.

63. С $\mathrm{CH}$. R. Post, $A$ bistory of Spanish..., op. cit., VIII, p. 623626, fig. 291, i R. Alcoy, "Obres Mestres de la pintura gòtica catalana...», op. cit., p. 195-210.

64. G. Macías i R. Cornudella, «El Retaule de sant Jordi...», op. cit., p. 228, n. 65 .

65. M. Meiss, «The Madonna of Humility...», op. cit., p. 461.

66. E. M. VetTeR, «Maria mit dem schreibenden...», op. cit., p. 125, fig. 15.

67. M. McDevitT, «"The ink of our mortality”...», op. cit., p. 235.

68. G. Macías i R. Cornudella, «El Retaule de sant Jordi...», op. cit., p. 227. Recordem també que una de les vidrieres del Saló del Trentenari de la Casa de la Ciutat incloïa la representació de les virtuts. A partir d'aquí, A. Duran I SANPERE, Barcelona $i$ la seva història..., op. cit., p. 100-101, suggerí que la taula de Martorell podia haver estat la traça d'aquesta vidriera. El 2 d'octubre de 1437 l'artista rebia efectivament un pagament per una vidriera destinada a la casa del Consell de Cent, però en desconeixem el tema. La vidriera amb les virtuts procedia de Flandes i s'hi va instal-lar el 1407.

69. A la Vulgata es llegeix: «Et si divitix appetuntur in vita, quid 
sapientia locupletius quæ operatur omnia? Si autem sensus operatur, quis horum qux sunt magis quam illa est artifex? Et si justitiam quis diligit, labores hujus magnas habent virtutes: sobrietatem enim et prudentiam docet, et justitiam, et virtutem, quibus utilius nihil est in vita hominibus».

70. La pintura havia estat atribuïda abans a Carlo da Camerino. Vegeu la informació proporcionada pel propi museu a $<$ https:// clevelandart.org/art/1916.795> (Consulta: 3 de març de 2020).

71. P. Verdier, a «La Vierge à l'Encrier...», p. 249, ja remarcava aquests dos aspectes.

72. La imatge i les dades sobre aquesta peça es poden consultar a la web del Cranach Digital Archive, concretament a $<$ http:// lucascranach.org/DE_MKH_ NONE-MKH001a>.

73. La talla havia estat inicialment atribuïda a Pere Sanglada, i fou Rosa Terés qui la ressituà al taller de Canet. Per a un estat de la qüestió recent, vegeu Cèsar Favà, «Atribuïda a Antoni Canet: Mare de Déu», a Catalunya 1400..., op. cit., p. 164-165.

74. M. Trens, María: Iconografía..., op. cit., p. 568, fig. 336.

75. Sens dubte es vincula també amb models forans, francesos, la Mare de Déu ara a l'Art Institute de Chicago però provinent d'una col-lecció privada catalana que Marta Crispí atribueix a Aloi de Montbrai a «Una obra documentada d'Aloi de Montbrai: La maredédeu de Prats de Rei», Locus Amoenus, 7, 2004, p. 111-116, fig. 3. En aquesta peça el Nen sosté per la «camisa» un llibre tancat.

\section{Vegeu nota 19.}

77. Florence Gombert i Didier Martens (2005), Primitifs flamands: Le Maître au Fenillage brodé. Secrets d'ateliers, París, RMN.

78. Sobre la Madonna Durán, vegeu Lorne Campbell i José Juan Pérez Preciado (2015), «Rogier van der Weyden: La Virgen con el Niño llamada La Madonna Duran", a Lorne CAmpbell (ed.), Rogier van der Weyden y los reinos de la Peninsula Ibérica, catàleg d'exposició, Madrid, Museo del Prado, p. 82-87. Sobre la versió de Bernardo de Aras, vegeu Didier Martens (2008), «Una huella de Rogier van der Weyden en la obra de Bernart de Aras "pintor vecino de la ciudat de Huesca" ", Archivo Español de Arte, 81, 321, p. 1-16. Existeixen altres versions de la Madonna Durán, com ara l'esculpida en pedra per Egas Cueman a la capella de santa Ana del Monestir de Santa Maria de Guadalupe, tal com ressenya la bibliografia citada.

79. John L. WARD (1971), «A proposed reconstruction of an Altarpiece by Rogier van der Weyden», The Art Bulletin, 53(1), p. 27-35, fig. 4, i Lorne CAmpbelL, «Vida y obra de Rogier van der Weyden», a Rogier van der Weyden..., op. cit., p. 15-31, esp. p. 23, fig. 6-7.

80. El retaule compta amb una bibliografia considerable que ara no exposarem pormenoritzadament. Vegeu-ne un recull complet a G. MACÍAs, La pintura aragonesa..., op. cit., p. 139, i a Alberto Velasco (2015), Pintura tardogòtica a l'Aragó i Catalunya: Pere Garcia de Benavarri, tesi doctoral, Lleida, Universitat de Lleida, cat. 13, p. 451 i següents.

81. Pertangué a Emili Cabot, i més tard a la colllecció Fontana. Ingresà al MNAC com a part del llegat d'aquesta darrera, el 1976 (Joan Ainaud [1976-1977], Donació Fontana: Catàleg, Barcelona, núm. 114.749).

82. La taula del Musée des Arts Décoratifs de París havia format part de la col-lecció d'Émile Peyre.

\section{Agustí Duran i Sanpere} (1977), Llibre de Cervera, Barcelona, Documents de Cultura 15.

84. Pel que fa a la proposta de reconstrucció, vegeu A. Velasco GonzÁlez (2007), «Mare de Déu i el Nen, sant Vicent Ferrer i donants: Professió de sant Vicenç Ferrer», a C. Bergés Saura, Patrimoni dispers: L'esplendor medieval a la Segarra, catàleg d'exposició, Cervera, Museu Comarcal de Cervera, p. 34-40, p. 37, a més dels estudis citats a la nota 80 .

85. A. Velasco, Pintura tardogòtica..., op. cit., p. 458, fig. 222-223.

86. Rematada el 2017 per 45.000 euros, provenia de la col-lecció Schäfer de Barcelona i ha estat declarada Bé d'Interés Cultural, la qual cosa la converteix en inexportable. Vegeu <https:// arsmagazine.com/la-tabla-degarcia-de-benabarre-se-vendepor-45-000-euros-en-la-suite/> (Consulta: 27 de febrer de 2020).

87. G. Macías, La pintura aragonesa..., op. cit., p. 140, nota
375 i 376, on s'inclou també la bibliografia anterior sobre les peces referenciades.

88. Ch. R. Post, A bistory of Spanish..., op. cit., VII, p. 275, suggeria la data de 1455 per al compartiment central del retaule, que atribuïa a Pere Garcia. El compartiment narratiu del Musée des Arts Décoratifs de París, en canvi, l'atribuïa al Mestre de Sant Quirze, que per ell sempre fou un mestre independent (ibídem, p. 212-213). També Joan Ainaud i Frederic Pau Verrié (1942), La pintura gótica en la catedral de Barcelona, Barcelona, inèdit, Arxiu Històric de la Ciutat de Barcelona (arxiu del "Premi Martorell"), p. 54, n. 28 , vinculen el retaule a la pintura barcelonina de Pere Garcia. A. Duran i Sanpere, a Barcelona i la seva història..., op. cit., p. 111-114, datà el retaule cap al 1455 o poc després.

89. Josep Maria Llobet (2003), «Algunes precisions sobre el retaule gòtic de la Mare de Déu i sant Vicenç Ferrer de l'església de Sant Domènec de Cervera», Butlletí del Museu Nacional d'Art de Catalunya, 7, p. 109-113, i ÍDEM (2013), «Més precisions sobre el retaule gòtic de la Mare de Déu i sant Vicenç Ferrer de l'església de Sant Domènec de Cervera», Urtx: Revista d'Humanitats de l'Urgell, 27, p. 159-161.

90. G. Macías, La pintura aragonesa..., op. cit., p. 125-129, i A. VELAsco, Pintura tardogòtica..., op. cit., cat. 6, p. 354 i següents.

91. La bibliografia sobre aquesta peça es recull a G. MAcías, La pintura aragonesa..., op. cit., p. 142, i A. Velasco, Pintura tardogòtica..., op. cit., cat. 16, p. 512 .

92. A. Velasco, Pintura tardogòtica..., op. cit., cat. 14, p. 504.

93. The Morgan Library and Museum, ms. 917 i 945 . Vegeu els estudis monogràfics següents: John Plummer (1966), The Hours of Catherine of Cleves, Londres, Barrie \& Rockliff, i Rob DüCKERS i Ruud Priem (2010), The Hours of Catherine of Cleves: Devotion, Demons and Daily Life in the Fifteenth Century, Nova York. Joaquín YARZa (1991), «Pere Garcia de Benavarri: Verge i Nen, sant Vicenç Ferrer i donants», a Francesca EsPAÑol i Esther Ratés (eds.), La Seu Vella de Lleida: La catedral, els promotors, els artistes. S. XIII a S. XV, Barcelona, Generalitat de Catalunya, p. 166-168, esp. p. 168, al-ludeix a aquesta connexió. 
94. Paulino Rodríguez BARRAL (2004), «La imagen del Juicio Final en la retablística gótica catalano-aragonesa, su función en el marco de empresas soteriológicas de carácter personal», Cuadernos de Arte e Iconografia, 13(26), p. 397-430, esp. p. 413-414.

95. A. Velasco, «Mare de Déu i el Nen...», op. cit., p. 38.

96. «Teniu temor de Déu i honoreu-lo perquè ja ve l'hora del seu judici», Apocalipsi 14, 6-7. A. Velasco, Pintura tardogòtica..., op. cit., p. 482, descriu el context en què sant Vicenç inclou aquest text de l'Apocalipsi en la seva prèdica. Óscar CALvé (2016), La configuración de la imagen de san Vicente Ferrer en el siglo XV, tesi doctoral, València, Universitat de València, p. 349-429, analitza de manera pormenoritzada com $i$ a partir de quins interessos i estímuls aquesta referència apocalíptica, «Timete Deum», es va convertir en clau en la definició de la personalitat i la prèdica (i, ensems, en la imatge artística) de sant Vicenç Ferrer.

97. E.M. VetTer, «Maria mit dem schreibenden...», op. cit., fig. 21.
98. Ch. P. Parkhurst JR., «The Madonna of...", op. cit., fig. 8 i 14.

99. Ibídem, fig. 12 i 10.

100. Edward Lewes CutTs (2018), Parish Priests and Their People in the Middle Ages in England, Frankfurt am Main, p. 156.

101. Ch. P. Parkhurst JR., «The Madonna of...», op. cit., fig. $20 \mathrm{i}$ 25.

102. W. Wixom, «An Enthroned Madonna...», op. cit., fig. 24.

103. MS M. $917 / 945$, p. $160-161$. 